University of Pennsylvania Carey Law School

Penn Law: Legal Scholarship Repository

Faculty Scholarship at Penn Law

3-6-2011

\title{
A Cost-Benefit Interpretation of the "Substantially Similar" Hurdle in the Congressional Review Act: Can OSHA Ever Utter the E-Word (Ergonomics) Again?
}

\author{
Adam M. Finkel \\ University of Pennsylvania \\ Jason W. Sullivan \\ Irell \& Manella LLP
}

Follow this and additional works at: https://scholarship.law.upenn.edu/faculty_scholarship

Part of the Administrative Law Commons, Business Law, Public Responsibility, and Ethics Commons, Environmental Law Commons, Health Economics Commons, Human Resources Management Commons, Labor and Employment Law Commons, Law and Economics Commons, Law and Politics Commons, Legislation Commons, and the Occupational Health and Industrial Hygiene Commons

\section{Repository Citation}

Finkel, Adam M. and Sullivan, Jason W., "A Cost-Benefit Interpretation of the "Substantially Similar" Hurdle in the Congressional Review Act: Can OSHA Ever Utter the E-Word (Ergonomics) Again?" (2011). Faculty Scholarship at Penn Law. 348.

https://scholarship.law.upenn.edu/faculty_scholarship/348

This Article is brought to you for free and open access by Penn Law: Legal Scholarship Repository. It has been accepted for inclusion in Faculty Scholarship at Penn Law by an authorized administrator of Penn Law: Legal Scholarship Repository. For more information, please contact PennlawIR@law.upenn.edu. 


\author{
IN THE CONGRESSIONAL REVIEW ACT: \\ CAN OSHA EVER UTTER THE E-WORD (ERGONOMICS) AGAIN?
}

\author{
ADAM M. FINKEL ${ }^{\dagger} \&$ JASON W. SULLIVAN ${ }^{\ddagger}$
}

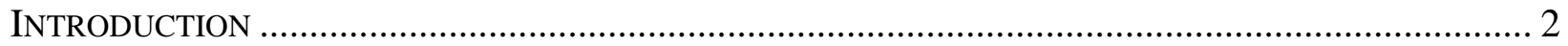

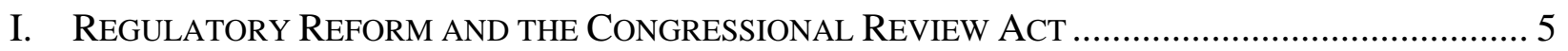

A. The 1994 Midterm Elections and Anti-Regulatory Sentiment ........................................... 6

B. The Contract with America and the CRA …………....................................................... 11

1. From Moratorium to Congressional Review ………….............................................. 11

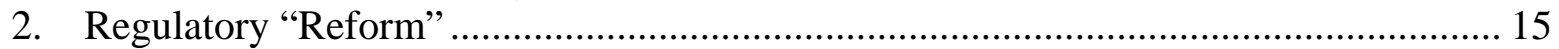

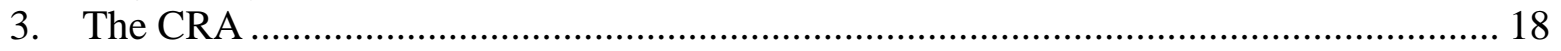

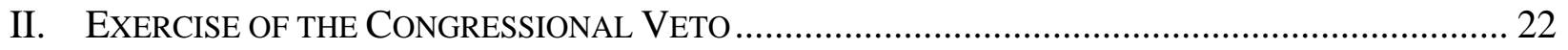

A. The OSHA Ergonomics Rule..................................................................................... 23

B. Midnight Regulations and Other Threats to Use the CRA ……………………................ 27

C. Enforcement of the Substantial Similarity Provision............................................................ 29

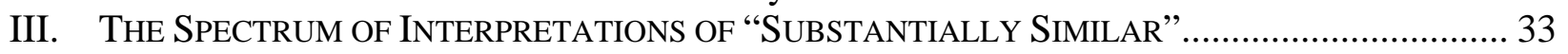

A. Hierarchy of Possible Interpretations.................................................................................. 33

B. How Others Have Interpreted "Substantially the Same" ...................................................... 38

IV. Why "SUBSTANTIALly the SAME" SHOULD Not BE INTERPRETED OMINOUSLY ................ 42

A. Congressional Intent and Language.................................................................................... 43

1. Events Leading up to Passage ....................................................................................... 45

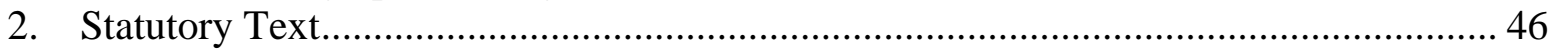

3. The "Signing Statement" ................................................................................................. 49

4. Ergonomics Floor Debate—Substantive Clues ............................................................ 54

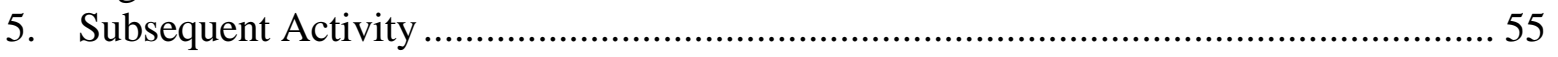

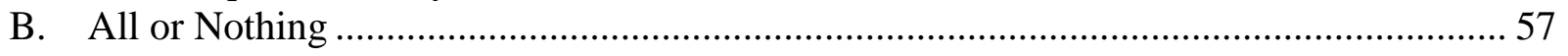

C. Deference to Agency Expertise................................................................................... 58

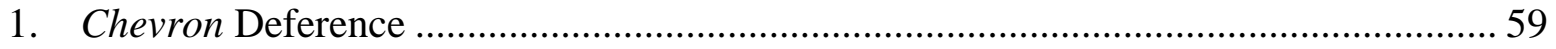

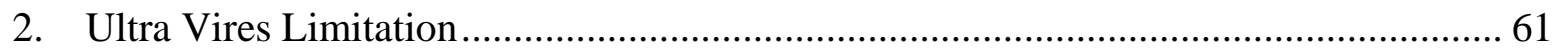

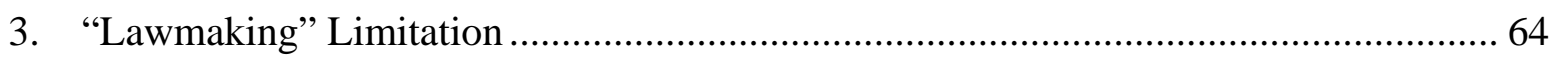

D. Good Government Principles........................................................................................... 68

1. Reluctance to Amend Congress's Delegation to the Agency ............................................. 69

${ }^{\dagger}$ Senior Fellow and Executive Director, Penn Program on Regulation, University of Pennsylvania Law School. Sc.D., Harvard School of Public Health, 1987. Prof. Finkel gratefully acknowledges the support for his OSHA reform work provided by the Public Welfare Foundation.

‡ Associate, Irell \& Manella LLP, Los Angeles, California. J.D., University of Pennsylvania, 2009. 
2. Other "Good Government” Rationales ................................................................ 71

V. What Does “Substantially the SAme” Really MEan?............................................. 72

VI. PRACTICAL IMPLICATIONS FOR OSHA OF A COST-BENEFIT INTERPRETATION OF THE CRA 76

A. Preconditions for a Sensible Discussion About the Stringency of an Ergonomics Rule.. 77

B. Specific Suggestions for Worthwhile Revisions to the Ergonomics Rule ....................... 82

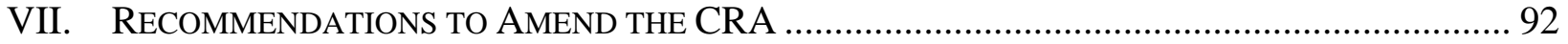

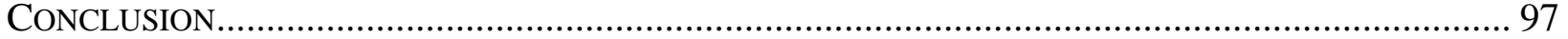

\section{INTRODUCTION}

Congress has always had the power to overturn a specific regulation promulgated by an executive branch agency, and, as the author of the underlying statutes under which the agencies regulate, has also always been able to amend those statutes so as to thwart entire lines of regulatory activity before they begin. But in 1996, Congress carved out for itself a shortcut path to regulatory oversight with the passage of the Congressional Review Act (CRA), ${ }^{1}$ and can now veto a regulation by passing a joint resolution rather than by passing a law. ${ }^{2}$ There is no question that Congress can now kill a regulation with relative ease; although it has only exercised that ability once in the fifteen years since the passage of the CRA. ${ }^{3}$ It remains ambiguous, however, whether Congress can use this new mechanism to, in effect, do to a regulation what the Russian nobles reputedly did to Rasputin—poison it, shoot it, stab it, and throw its weighted body into a river - that is, to veto not only the instant rule it objects to, but forever bar an agency from regulating in that area. From the point of view of the agency, the question is, "What kind of phoenix, if any, is allowed to rise from the ashes of a dead regulation?” This is a subject that has

${ }^{1}$ Congressional Review Act of 1996, Pub. L. No. 104-121, 110 Stat. 868-74 (codified as amended at 5 U.S.C. $\S \S 801-808$ (2006)).

2 See 5 U.S.C. $\S \S 801-802$ (2006).

${ }^{3}$ See infra Part II.A (discussing the OSHA ergonomics rule and the congressional veto thereof in 2001). 
in our view been surrounded by mystery and misinterpretations, and is the area we hope to clarify via this Article.

A coherent and correct interpretation of the key clause in the CRA, which bars an agency from issuing a new rule that is "substantially the same" as one vetoed under the CRA, ${ }^{4}$ matters most generally as a verdict on the precise demarcation of the relative power of Congress and the executive; it matters broadly for the administrative state, as all agencies puzzle out what danger they court by issuing a rule that Congress might veto (can they and their affected constituents be worse off for having awakened the sleeping giant than had they issued no rule at all?), and it matters most specifically for the U.S. Occupational Safety and Health Administration (OSHA), whose new Assistant Secretary ${ }^{5}$ is almost certainly pondering whether any attempt by the agency to regulate musculoskeletal disorders (“ergonomic” hazards) in any fashion would run afoul of the "substantially the same" prohibition in the CRA.

In this Article, we offer the most reasonable interpretation of the three murky words "substantially the same” in the CRA. Because neither Congress nor any reviewing court has yet been faced with the need to consider a reissued regulation for "substantial similarity" to a vetoed one, this is "uncharted legal territory."6 The range of plausible interpretations runs the gamut from the least daunting to the most ominous (from the perspective of the agencies), as we will describe in detail in Part III.A. To foreshadow the extreme cases briefly, it is conceivable that even a verbatim identical rule might not be “substantially similar” if scientific understanding of the hazard or the technology to control it had changed radically over time, but it is also

${ }^{4} 5$ U.S.C. § 801(b)(2).

${ }^{5}$ David Michaels, confirmed December 3, 2009. See 155 Cong. REC. S12351 (daily ed. Dec. 3, 2009). 
conceivable that any subsequent attempt to regulate in any way whatsoever in the same broad topical area would be barred. ${ }^{7}$ We will show, however, that considering the legislative history of the CRA and the subsequent expressions of congressional intent issued during the one legislative veto of an agency rule to date, as well as considering the bedrock principles of good government in the administrative state, an interpretation of "substantially similar" much closer to the former than the latter end of this spectrum is most reasonable and correct. We conclude that the CRA permits an agency to reissue a rule that is very similar in content to a vetoed rule, so long as it produces a rule with a significantly more favorable balance of costs and benefits than the vetoed rule.

We will assert that our interpretation of "substantially similar” is not only legally appropriate, but arises naturally when one grounds the interpretation in the broader context that motivated the passage of the CRA and that has come to dominate both legislative- and executivebranch oversight of the regulatory agencies: the insistence that regulations should generate benefits in excess of their costs. We assert that even if the hazards addressed match exactly those covered in the vetoed rule, if a reissued rule has a substantially different cost-benefit equation than the vetoed rule, then it cannot be regarded as "substantially similar" in the sense in which those words were intended.

The remainder of this Article will consist of seven Parts. In Part I, we will lay out the political background of the 104th Congress, and then explain both the substance and the legislative history of the Congressional Review Act. In Part II, we discuss the one instance in

\footnotetext{
${ }^{6}$ Kristina Sherry, “Substantially the Same” Restriction Poses Legal Question Mark for Ergonomics, INSIDE OSHA, Nov. 9, 2009, at 1, 1, 8.

${ }^{7}$ See infra Part III.A.
} 
which the fast-track congressional veto procedure has been used successfully, and mention other contexts in which Congress has considered using it to repeal regulations. In this Part, we also discuss the further "uncharted legal territory" of how the courts might handle a claim that a reissued rule was "substantially similar." In Part III, we present a detailed hierarchy of possible interpretations of "substantially similar," and in Part IV, we explain why the "substantial similarity” provision should be interpreted in among the least ominous ways available. In Part $\mathrm{V}$, we summarize the foregoing arguments and give a brief verdict on exactly where in the seven-level hierarchy we developed we think "substantially similar” must be interpreted to fall. In Part VI, we discuss some of the practical implications of our interpretation for OSHA as it considers its latitude to propose another ergonomics rule. Finally, in Part VII, we recommend some changes in the system to help achieve Congress' original aspirations with less inefficiency and ambiguity.

\section{REgulatory ReForm AND tHe CONGRESSiONAL REVIEW ACT}

The Republican Party's electoral victory in the 1994 midterm elections brought with it the prospect of sweeping regulatory reform. As the Republicans took office in the 104th Congress, they credited their victory to public anti-government sentiment, especially among the small business community. ${ }^{8}$ Regulatory reform was central to the House Republicans' ten-plank “Contract with America” proposal, which included provisions for congressional review of pending agency regulations and an opportunity for both houses of Congress and the President to

\footnotetext{
${ }^{8}$ See infra Part I.A.
} 
veto a pending regulation via an expedited process. ${ }^{9}$ This Part discusses the Contract with America and the political climate in which it was enacted.

\section{A. The 1994 Midterm Elections and Anti-Regulatory Sentiment}

An understanding of Congress's goal for regulatory reform requires some brief familiarity with the shift in political power that occurred prior to the enactment of the Contract with America. In the 1994 elections, the Republican Party attained a majority in both houses of Congress. In the House of Representatives, Republicans gained a twenty-six seat advantage over the House Democrats. ${ }^{10}$ Similarly, in the Senate, Republicans turned their minority into a fourseat advantage. ${ }^{11}$

The 1994 election included a significant increase in participation among the business community. In fact, a significant majority of the incoming Republican legislators were members of that community. ${ }^{12}$ Small business issues—and in particular the regulatory burden—were central issues in the midterm election, and many credited the Republican Party’s electoral victory

${ }^{9}$ Congressional Review Act of 1996, Pub. L. No. 104-121, 110 Stat. 868-74 (codified as amended at 5 U.S.C. §§ 801-808 (2006)).

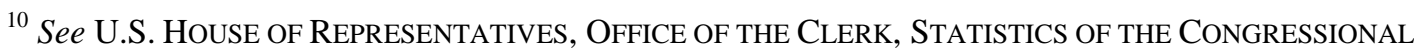
ELECTION OF NOVEMBER 8, 1994 (1995), available at http://clerk.house.gov/member_info/electionInfo/1994/ 94Stat.htm (reporting the results of the 1994 U.S. House elections, in which the Republicans won a majority of 230204).

${ }^{11}$ See id. (reporting the results of the 1994 U.S. Senate elections, after which the Republicans held a majority of 52-48).

${ }^{12}$ Newt Gingrich, foreword to Richard Lesher, Meltdown on Main StreEt: Why SMALl Business Is Leading the Revolution Against Big Government, at xi, xiv (1996) (“Of the 73 freshman Republicans elected to the House in 1994, 60 were small businesspeople ....”). 
to its anti-regulatory position. ${ }^{13}$ Of course, it was not only business owners who campaigned to decrease the volume of federal regulation—seeking more autonomy and fewer compliance costs, farmers and local governments also aimed to decrease the size of the federal government. ${ }^{14}$

One catalyst for the wave of anti-government sentiment and the Republicans’ related electoral victory was the increasing regulatory burden. By some estimates, the annual costs of federal regulation had increased over $\$ 100$ billion in one decade, rising from an estimated \$469 billion in 1986 to an estimated $\$ 607$ billion in 1995 . $^{15}$

Regulatory reform was not merely an idle campaign promise. Republicans had spent a great deal of effort in prior years to push for fewer regulations, to no avail. When the 104th Congress was sworn in, changes to the regulatory process ranked highly on the Republican Party’s agenda. ${ }^{16}$ The party leaders were aggressive in their support of regulatory reform. Senator Don Nickles of Oklahoma declared, “We're going to get regulatory reform . ... We can do it with a rifle or we can do it with a shotgun, but we're going to do it.”17

The case that the federal government had been hurtling towards a coercive "nanny state," and the need to deregulate (or at least to slam on the brakes) in response, was bolstered in the

${ }^{13}$ See, e.g., Linda Grant, Shutting Down the Regulatory Machine, U.S. NEWs \& WorLD REP., Feb. 13, 1995, at 70 ("Resentment against excessive government regulation helped deliver election victory to Republicans ....”).

${ }^{14}$ See id. at 72 ("Business has gained a number of allies in its quest to rein in regulation. State and local governments, ranchers and farmers, for example, also want to limit Washington's role in their everyday dealings.”).

${ }^{15} \mathrm{Id}$. (reporting the annual costs of federal regulation in 1991 dollars).

${ }^{16}$ See, e.g., Bob Tutt, Election '94: State; Hutchinson Pledges to Help Change Things, HousTON CHRON., Nov. 9, 1994, at A35 (reporting that Senator Kay Bailey Hutchinson of Texas named "reduction of regulations that stifle small business" as one of the items that "had her highest priority”). Nickles).

${ }^{17}$ Stan Crock et al., A GOP Jihad Against Red Tape, Bus. WK., Nov. 28, 1994, at 48 (quoting Senator 
early 1990s by a confluence of new ideas, new institutions, and new advocates. ${ }^{18}$ The rise of quantitative risk assessment (QRA), and the rapid increase in the capability of analytical chemistry to detect lower and lower amounts of contaminants in all environmental media and human tissues, made possible an ongoing stream of revelations about the apparent failure to provide an "ample margin of safety” below safe levels of substances capable of causing chronic disease and ecological damage. But at the same time, the successes of the 1970s and 1980s at picking the "low-hanging fruit" of the most visible manifestations of environmental pollution (flaming rivers; plumes of soot rising from major point sources) made possible a compelling counter-argument: that unlike the first generation of efficient remedies for intolerable problems, the "mopping up” of the last increments of pollution threatened to cost far more than the (dubious) benefits achieved. This view was supported by the passage of time and the apparent lack of severe long-term consequences from some of the environmental health crises of the early 1980s (e.g., Love Canal, New York and Times Beach, Missouri). ${ }^{19}$ In the early 1990s, several influential books advanced the thesis that regulation was poised to impose severe harm for little or non-existent benefit, notably The Death of Common Sense: How Law Is Suffocating America, ${ }^{20}$ which decried the purported insistence on inflexible and draconian strictures on

18 This section, and the subsequent section on the regulatory "reform" legislation of the mid-1990s, is informed by one of our (A.F.) experience as an expert in methods of quantitative risk assessment, and (when he was Director of Health Standards at OSHA from 1995-2000) a "point person” in the executive agencies providing expertise in risk assessment and cost-benefit analysis during the series of discussions between the Clinton administration and congressional staff and members.

${ }^{19}$ See generally Associated Press, Around the Nation; Times Beach, Mo., Board Moves to Seal Off Town, N.Y. TiMES, Apr. 27, 1983 (reporting attempts by officials to blockade a St. Louis suburb that had been contaminated by dioxin), available at http://http:/query.nytimes.com/gst/fullpage.html?res= 9403E0D71438F934A15757C0A965948260; Eckardt C. Beck, The Love Canal Tragedy, E.P.A. J., Jan. 1979 (describing the tragedy following the discovery of toxic waste buried beneath the neighborhood of Love Canal, New York), available at http://www.epa.gov/history/topics/lovecanal/01.htm.

${ }^{20}$ Philip K. Howard, The DeAth of Common Sense: How LAW Is SufFocating America (1994). 
business, and Breaking the Vicious Circle. ${ }^{21}$ In this latter book, then-Judge Stephen Breyer posited a cycle of mutual amplification between a public eager to insist on zero risk and a cadre of risk assessors and bureaucrats happy to invoke "conservative” interpretations of science to exaggerate the risks that remained uncontrolled. Although the factual basis for the claim that risk assessment is too "conservative" (or even that it does not routinely underestimate risk) was and remains controversial, ${ }^{22}$ enough of the individual common assumptions used in risk assessment were so clearly “conservative” (e.g., the use of the upper confidence limit when fitting a dose-response function to cancer bioassay data) that this claim had considerable intuitive appeal. Around the same time, influential think-tanks and trade associations (e.g., the Cato Institute, the American Council on Science and Health) echoed the indictment against overregulation, and various media figures (notably John Stossel) advanced the view that the U.S. public was not just desirous of a safer world than common sense would dictate, but had scared itself into irrationality about how dangerous the status quo really was. ${ }^{23}$

The scholars and advocates who made the most headway with Congress in the period leading up to the passage of the CRA made three related, compelling, and in our opinion very politically astute arguments that still influence the landscape of regulation 15 years later. First, they embraced risk assessment—-thereby proffering a "sound science" alternative to the disdain for risk assessment most mainstream and grassroots environmental groups have historically

${ }^{21}$ Stephen Breyer, BREAKing THE Vicious Circle: TOWARD EFFeCtive RisK REgUlation (1993).

${ }^{22}$ See Adam M. Finkel, Is Risk Assessment Really Too "Conservative”?: Revising the Revisionists, 14 COLUM. J. ENVTL. L. 427 (1989) (discussing numerous flaws in the assertion that risk assessment methods systematically exaggerate risk, citing aspects of the methods that work in the opposite direction and citing empirical evidence contrary to the assertion).

${ }^{23}$ Are We Scaring Ourselves to Death? (ABC television broadcast April 21, 1994). 
expressed $^{24}$ —although they insisted that each allegedly "conservative" assumption should be ratcheted back. Second, they advocated for the routine quantitative comparison of benefits (risks reduced) to the cost of regulation, thereby throwing cold water even on large risks if it could be shown that once monetized, the good done by controlling them was outweighed by the economic costs of that control. And perhaps most significantly, they emphasized—particularly in the writings and testimony of John Graham, who went on to lead the White House Office of Information and Regulatory Affairs in the George W. Bush administration—-that regulatory overkill was tragic not just because it was economically expensive, but because it could ill serve the very goal of maximizing human longevity and quality of life. Some regulations, Graham and others emphasized ${ }^{25}$ could create or exacerbate similar or disparate risks, and do more harm to health and the environment than inaction would. Many other stringent regulations could produce non-negative net benefits, but far less benefit than could "smarter regulation.” Graham famously wrote and testified that going after trace amounts of environmental pollution, while failing to regulate risky consumer products (e.g., via bicycle helmet requirements) or to support highly cost-effective medical interventions, amounted to the "statistical murder" of approximately 60,000 Americans annually whose lives could have been saved with different regulation, as opposed to deregulation per se. ${ }^{26}$

${ }^{24}$ See Alon Tal, A Failure to Engage, ENVTL. F., Jan-Feb. 1997, at 13-21.

${ }^{25}$ See Risk Versus Risk: Tradeoffs in Protecting Health and the Environment (John D. Graham \& Jonathan Baert Weiner, eds., 1995); see also Cass R. Sunstein, Health-Health Tradeoffs (Chi. Working Papers on Law \& Econ., No. 42, 1996), available at http://www.law.uchicago.edu/files/files/42.CRS_.Health.pdf.

${ }^{26}$ Republican Representative John Mica stated:

Let me quote John Graham, a Harvard professor, who said, "Sound science means saving the most lives and achieving the most ecological protection with our scarce budgets. Without sound science, we are engaging in a form of statistical murder when we squander our resources on phantom risks when our families continue to be endangered by real risks."

142 ConG. REC. H2255 (daily ed. Feb. 27, 1995) (statement of Rep. Mica). 
The stage was thus set for congressional intervention to "rationalize” (or, perhaps, to undermine) the federal regulatory system.

\section{B. The Contract with America and the CRA}

When the Republicans in the 104th Congress first began drafting the Contract with America, they intended to stop the regulatory process in its tracks by imposing a moratorium on the issuance of any new regulations. After the Clinton administration resisted calls for a moratorium, Congress compromised by substituting the proposed moratorium with an amendment to the Administrative Procedure Act (APA) that allowed Congress and the President to veto pending regulations via an expedited process. ${ }^{27}$ This compromise led to a subtitle in the Contract with America now known as the Congressional Review Act of 1996 (CRA). This Section describes the history of the CRA and its substance as enacted.

\section{From Moratorium to Congressional Review}

Even before being sworn in, GOP leaders had their sights set on imposing a moratorium on the issuance of all new federal regulation, and urged President Clinton to implement a moratorium himself. ${ }^{28}$ When he declined to do so, ${ }^{29}$ House Republicans called for a legislative

${ }^{27}$ See infra Part I.B.3.

${ }^{28}$ See Melissa Healy, GOP Seeks Moratorium on New Federal Regulations, L.A. TIMES, Dec. 13, 1994, at A32 (reporting that House Speaker Newt Gingrich of Georgia and Senate Majority Leader Bob Dole of Kansas sent a letter to the White House urging President Clinton to issue an executive order imposing a moratorium on new federal rules).

${ }^{29}$ See Letter from Sally Katzen, Executive Office of the President, Office of Mgmt. \& Budget, to Tom DeLay, U.S. House of Representatives (Dec. 14, 1994), reprinted in H.R. REP. No. 104-39, pt. 1, at 38-39 (1995) 
solution - they intended to enact a statute that would put a moratorium on new regulations ${ }^{30}$, so that Congress could implement regulatory reform without the distraction of having the federal bureaucracy continue to operate. A moratorium would also allow any new standards to be applied to all pending regulations without creating a "moral hazard”-agencies rushing to get more rules out (especially more unpalatable ones), in advance of a new set of strictures. ${ }^{31}$ members of Congress put particular emphasis on the importance of cost-benefit analysis (CBA) and risk assessment, noting that the moratorium might be lifted early if stricter CBA guidelines were implemented. ${ }^{32}$ These ideas formed the basis of H.R. 450, the proposed Regulatory Transition Act of 1995, which would have imposed a retroactive moratorium period starting November 20, 1994 and lasting until either December 31, 1995 or the date that CBA or risk assessment requirements were imposed, whichever would come earlier. ${ }^{33}$

The proposed moratorium, despite passing in the House, ${ }^{34}$ met strong opposition in the Senate. Although Senate committees recommended enactment of the moratorium for largely the same reasons as the House leadership, ${ }^{35}$ a strong minority joined the Clinton administration in

(expressing, on behalf of President Clinton, concern about the efficiency of federal regulation but declining to issue an executive order imposing a moratorium on federal regulation).

${ }^{30}$ See Grant, supra note 13, at 70 (“To halt rampant rule making, Rep. David McIntosh . . . co-sponsored a bill with House Republican Whip Tom DeLay that calls for a moratorium on all new federal regulation ... . ”).

${ }^{31}$ See H.R. REP. No. 104-39, pt. 1, at 9-10 (1995) (“[A] moratorium will provide both the executive and the legislative branches ... . with more time to focus on ways to fix current regulations and the regulatory system. Everyone involved in the regulatory process will be largely freed from the daily burden of having to review, consider and correct newly promulgated regulations . . . ”); S. REP. No. 104-15, at 5 (1995) (same).

${ }^{32}$ See H.R. REP. No. 104-39, pt. 1, at 4 (“The moratorium can be lifted earlier, but only if substantive regulatory reforms (cost/benefit analysis and risk assessment) are enacted.”); see also id. (noting that agencies would not be barred from conducting CBA during the moratorium).

${ }^{33}$ H.R. 450, 104th Cong. $\S \S 3(a), 6(2)$ (as passed by House of Representatives, Feb. 24, 1995).

34141 CONG. REC. H2210 (daily ed. Feb. 24, 1995) (reporting roll call vote of 276-146, with 13 Representatives not voting).

35 See S. 219, 104th Cong. (as reported by S. Comm. on Governmental Affairs, Mar. 16, 1995) (proposing a moratorium similar to that considered in the House, but with a retroactivity clause that reached even further back); 
opposition to the bill. ${ }^{36}$ Six of the fourteen members of the Senate Committee on Governmental Affairs argued that a moratorium was overbroad and wasteful, and "does not distinguish between good and bad regulations.”37 In their view, a moratorium would hurt more than it would help, since it would "create delays in good regulations, waste money, and create uncertainty for citizens, businesses, and others.”38 ${ }^{\text {The Republicans, with only a slim majority in the Senate, }}{ }^{39}$ would face difficulty enacting a moratorium.

While H.R. 450 had been working its way through the House, Senate Republicans drafted a more moderate (and, from the Senate's perspective, more realistic) proposal for regulatory reform through congressional oversight—Senate bill S. 348 would set up an expedited congressional review process for all new federal regulations and allow for their disapproval by enactment of a joint resolution. ${ }^{40}$ When faced with a Senate that was closely split over the moratorium bill, Senators Don Nickles of Oklahoma and Harry Reid of Nevada reached a compromise - they introduced the text of S. 348 as a substitute for the moratorium proposal, and it became known as the Nickles-Reid Amendment. ${ }^{41}$ Senate Democrats saw the more nuanced

see also S. REP. No. 104-15, at 1 ("The Committee on Governmental Affairs ... reports favorably [on S. 219] and recommends that the bill ... do pass.”).

${ }^{36}$ See S. REP. No. 104-15, at 25-32 (calling the moratorium "dangerous" and "unnecessary”); see also Letter from Sally Katzen to Tom DeLay, supra note 29 (calling the moratorium a "blunderbuss” and noting that it was so overbroad that it would impede regulations addressing tainted meat in the food supply and assisting the diagnosis of illnesses that veterans may have suffered while serving in the Persian Gulf War).

${ }^{37}$ S. REP. NO. 104-15, at 25.

${ }^{38} I d$. at 26.

${ }^{39}$ See supra note 11 and accompanying text.

40 S. 348, 104th Cong. (as introduced in Senate, Feb. 2, 1995).

${ }^{41}$ See 141 Cong. REC. S4699 (daily ed. Mar. 28, 1995) (statement of Sen. Baucus) (noting withdrawal of the moratorium in favor of a fast-track process for congressional review). 
review process as a significant improvement over the moratorium’s prophylactic approach, ${ }^{42}$ and the proposal (S. 219) passed the chamber by a roll call vote of $100-0 .{ }^{43}$

Disappointed in the defeat of their moratorium proposal, House leaders did not agree on a conference to reconcile H.R. 450 with S. $219 .{ }^{44}$ Pro-environment House Republicans eventually convinced House leaders that their antiregulatory plans were too far-reaching, ${ }^{45}$ and over the following year members of Congress attempted to include the review provision in several bills. However, each bill eventually failed for reasons unrelated to the congressional review provision. ${ }^{46}$ The provision was finally successfully included as Subtitle E of the Small Business Regulatory Enforcement Fairness Act of 1996 (SBREFA), a part of the larger Contract with America Advancement Act (CWAA). ${ }^{47}$ The congressional review provision was ultimately enacted without debate, as more controversial parts of the Contract with America occupied Congress’s attention. ${ }^{48}$ On March 28, 1996, the CWAA passed both houses of Congress. ${ }^{49}$

${ }^{42}$ See id. ("To my mind, this amendment is much closer to the mark. ... Congress can distinguish good rules from bad. ... [I]f an agency is doing a good job, the rule will go into effect, and public health will not be jeopardized.”).

43 See S. 219, 104th Cong. (as passed by Senate, Mar. 29, 1995) (including the congressional review procedure in lieu of the moratorium proposal); 141 CoNG. REC. S4758 (daily ed. Mar. 29, 1995) (reporting the roll call vote).

${ }^{44}$ See 142 Cong. REC. E575 (daily ed. Apr. 19, 1996) (speech of Rep. Hyde) (discussing the procedural history of the CRA).

${ }^{45}$ See John H. Cushman, House G.O.P. Chiefs Back Off on Stiff Antiregulatory Plan, N.Y. TIMES, Mar. 6, 1996, at A19 ("Representative Sherwood Boehlert, a Republican from upstate New York who has emerged as the leader of a block of pro-environment House members, persuaded Speaker Newt Gingrich at a meeting today that this legislation went too far.”).

${ }^{46}$ See 142 Cong. REC. E575 (daily ed. Apr. 19, 1996) (speech of Rep. Hyde) (discussing the procedural history of the CRA).

${ }^{47}$ See Small Business Regulatory Enforcement Fairness Act of 1996, Pub. L. No. 104-121, 110 Stat. 857, 868-74 (codified as amended at 5 U.S.C. §§ 801-808 (2006)).

${ }^{48}$ See 142 CONG. REC. E571-79 (daily ed. Apr. 19, 1996) (speech of Rep. Hyde) (inserting documents into the legislative history of the CWAA several weeks after its enactment, and noting that "no formal legislative history document was prepared to explain the [CRA] or the reasons for changes in the final language negotiated between the 
When President Clinton signed the bill into law, he issued a signing statement that he had "long supported” the idea of increasing congressional accountability via a review procedure, but he also noted his reservations about some of the provision's specific terms, which he said "will unduly complicate and extend” the process. ${ }^{50}$

\section{Regulatory "Reform"}

On a parallel track with the idea of a regulatory moratorium during 1994-1996, both houses of Congress were considering far more detailed and sweeping changes to the way federal agencies could regulate. As promised by Speaker Newt Gingrich, within 100 days of the installation of 104th Congress, H.R. 1022, the “Job Creation and Wage Enhancement Act” was introduced and voted on. This bill would have required most regulations to be justified by a judicially-reviewable QRA, performed under a set of very specific requirements regarding the appropriate models to select and the statistical procedures to use. It also would have required agencies to certify that each rule produced "benefits to human health or the environment that justify the costs incurred.” Although this bill passed the House by a vote of 277-141, the Republican Senate majority had made no public pledge to reform regulation as had their House counterparts, ${ }^{51}$ and the similar Senate bill (S. 343, the "Comprehensive Regularatory Reform Act,” sponsored primarily by Republican Robert Dole of Kansas and Democrat S. Bennett

House and Senate”); 142 Cong. REC. S3683-87 (daily ed. Apr. 18, 1996) (joint statement of Sens. Nickles, Reid, and Stevens) (same).

${ }^{49}$ See 142 CONG. REC. H3028 (daily ed. Mar. 28, 1996) (reporting the House roll call vote of 328-91 with 12 non-voting Representatives, including several liberals voting for the bill and several conservatives voting against it); 142 Cong. REC. S3114 (daily ed. Mar. 28, 1996) (reporting the Senate unanimous consent motion).

${ }^{50}$ Statement by President William J. Clinton upon Signing H.R. 3136, 32 WeEKLY CoMP. Pres. Doc. 593 (Apr. 8, 1996), reprinted in 1996 U.S.C.C.A.N. at 606-1 to 606-2. 
Johnston of Louisiana), occupied that body for months of debate. Three separate cloture votes were taken in the summer of 1995, the final one falling only two votes shy of the 60 needed to end debate.

Professors Landy and Dell attribute the failure of S. 343 largely to Presidential politics: Senator Dole (who won the Republican nomination that year) may have been unwilling to tone down the judicial review provisions (under which agencies would face remand for deficiencies in their risk assessments or disputes over their cost-benefit pronouncements) because he was looking to his base, while President Clinton threatened a veto as an attempt to "tap into the public’s long-standing support for environmental regulation." ${ }^{52}$ However, there were serious substantive issues afoot as well. Public-interest groups were very active opponents of S. 343; with each untoward event in the news as the debate continued (notably a cluster of deaths and illnesses caused by fast-food hamburgers contaminated with E. coli), the bill's "green eyeshade" tone (dissect all costs and benefits, giving inaction in the seeming benefit of the doubt) became a flashpoint for concern. For its part, the White House aggressively charted its own course of reform, strengthening the executive order giving OIRA broad authority over regulatory agencies, and making regulatory transparency and plain language cornerstones of Vice President Gore’s broader "Reinventing Government” initiative. Graham concluded that "the Democratic leadership made a calculation that it was more profitable to accuse Republicans of rolling back

${ }^{51}$ See Marc Landy \& Kyle D. Dell, The Failure of Risk Reform Regulation in the 104th Congress, 9 DuKE ENVTL. L. \& POL'Y F. 115-16.

${ }^{52}$ See Landy \& Dell, supra note 51, at 125. 
protections (in the guise of reform) than it was to work collaboratively toward passage of the bipartisan regulatory reform measure.,53

Nevertheless, the fact remains that the majority of both houses believed that each federal regulation should be able to pass a formal benefit-cost test. Although neither this requirement nor the blueprint for how benefits and costs had to be quantified was enshrined in law, the passage of the CRA less than a year after the failure to pass the Dole-Johnston bill can most parsimoniously be interpreted as Congress asserting that if the agencies remained free to promulgate rules with an unfavorable cost-benefit balance, Congress could veto at the finish line what a "regulatory reform" law would have instead nipped in the bud.

The CRA could also be interpreted as one of four contemporaneous attempts to salvage as much as possible of the cost-benefit agenda embodied in the failed omnibus regulatory reform legislation. ${ }^{54}$ During 1995-1996, Congress also enacted the Unfunded Mandates Reform Act (which requires agencies to quantify regulatory costs to state and local governments, and to respond in writing to suggestions from these stakeholders for alternative regulatory provisions that could be more cost-effective), the Regulatory Compliance Simplification Act (which requires agencies to prepare compliance guides directed specifically at small businesses), and a series of amendments to the Regulatory Flexibility Act (which makes judicially reviewable the agency's required analysis of why it should not adopt less costly regulatory alternatives favoring small businesses). Against this backdrop, the CRA more clearly serves the primary purpose of

${ }^{53}$ John D. Graham, Legislative Approaches to Achieving More Protection Against Risk at Less Cost, 1997 U. CHI. LEGAL F. 13, 57. However, as a participant in numerous executive-branch and congressional discussions at the time, one of us (A.F.) hastens to add that many in the executive agencies believed that many of the specific provisions in the Dole-Johnston bill were in fact punitive, and were indeed offered merely "in the guise of reform." 
giving special scrutiny—before aggrieved parties would have to plead their case in court—-to rules that arguably run afoul of other strong signals from Congress about the desired flexibility and cost-effectiveness of agency regulatory proposals.

\section{The CRA}

The CRA established a procedure by which Congress can oversee and, with the assent of the President, veto rules being promulgated by federal agencies. Before any rule can take effect, the agency promulgating the rule must submit to the Senate, House of Representatives, and the Comptroller General of the Government Accountability Office (GAO) a report containing, among other things, the rule and its complete CBA (if one is required). ${ }^{55}$ The rule is then submitted for review to the chairman and ranking member of each relevant committee in each chamber. ${ }^{56}$ Some rules-for example, rules pertaining to internal agency functioning, or any rule promulgated by the Federal Reserve System—are exempted from undergoing this procedure. ${ }^{57}$

During this review process, the effective date of any "major rule" is postponed. ${ }^{58}$

However, the President has discretion to allow a major rule that would otherwise be suspended to

\footnotetext{
${ }^{54}$ James T. O’Reilly, EPA Rulemaking After the 104th Congress: Death from Four Near-Fatal Wounds?, 3 ENVTL. L. 1, 1.

555 U.S.C. § 801(a)(1)(A)-(B) (2006). Senator Pete Domenici of New Mexico inserted the provision
} requiring submission of the report to the Comptroller General because GAO would be able to effectively review the CBA and ensure that the regulation complies with legal requirements, such as unfunded mandates legislation. See 141 Cong. Rec. S4700-01 (daily ed. Mar. 28, 1995) (statement of Sen. Domenici).

${ }^{56} 5$ U.S.C. $\S 801(\mathrm{a})(1)(\mathrm{C})$.

${ }^{57}$ Id. § 804(3) (defining "rule" for the purposes of the CRA so as to exclude certain categories); id. § 807 (exempting all regulations promulgated by the Federal Reserve and Federal Open Market Committee from CRA requirements).

${ }^{58} I d$. § 801(a)(3). A "major rule” under the CRA is any rule that: (1) has an annual effect on the economy of \$100 million or more; (2) results in a "major increase in costs or prices" for various groups, such as consumers and industries; or (3) is likely to result in "significant adverse effects on competition, employment, investment," or 
go into effect for a limited number of purposes, such as national security. ${ }^{59}$ The statute also exempts from suspension any rule for which the agency finds "for good cause . . . that notice and public procedure thereon are impracticable, unnecessary, or contrary to the public interest . . . „60

If Congress chooses to repeal any rule subject to the CRA, it may pass a joint resolution of disapproval via an expedited process. The procedure is expedited in order "to try to provide Congress with an opportunity to act on resolutions of disapproval before regulated parties must invest the significant resources necessary to comply with a major rule." ${ }^{61}$ From the date that the agency submits its report of the rule, Congress has sixty legislative days in which to pass a joint resolution. ${ }^{62}$ The procedure is expedited in the Senate, where debate over a joint resolution of disapproval is limited to a maximum of ten hours, effectively preventing any possibility of a filibuster. ${ }^{63}$ The House does not have an expedited procedure, however. ${ }^{64}$ When a disapproval

other types of enterprise abilities. Id. § 804(2). Any rule promulgated under the Telecommunications Act of 1996 is not a major rule for purposes of the CRA. Id.

${ }^{59} I d . \S 801$ (c).

${ }^{60} I d$. § 808. The "good cause" exception is intended to be limited to only those rules that are exempt from notice and comment by statute. See 142 Cong. REC. E576 (daily ed. Apr. 19, 1996) (speech of Rep. Hyde).

${ }^{61} 142$ Cong. REC. S3685 (daily ed. Apr. 18, 1996) (joint statement of Sens. Nickles, Reid, and Stevens); see also 147 CONG. REC. S1833 (daily ed. Mar. 6, 2001) (statement of Sen. Jeffords) (noting that "scarce agency resources are also a concern" that justifies a stay on the enforcement of major rules).

${ }^{62} 5$ U.S.C. § 802(a). The sixty-day window excludes "days either House of Congress is adjourned for more than 3 days during a session of Congress ....” Id. If an agency submits a report with fewer than sixty days remaining in the session of Congress, the sixty-day window is reset, beginning on the fifteenth day of the succeeding session of Congress. See id. §§ 801(d)(1), 801(d)(2)(A).

${ }^{63}$ Id. § 802(d)(2); cf. STANDING RULES OF THE SENATE R. XXII § 2 (2010) (requiring the affirmative vote of three-fifths of Senators to close debate on most legislative actions).

${ }^{64}$ See also Morton Rosenberg, Whatever Happened to Congressional Review of Agency Rulemaking?: A Brief Overview, Assessment, and Proposal for Reform, 51 ADMIN. L. REV. 1051, 1063 (1999) (criticizing the CRA for its lack of an expedited House procedure because, "[a]s a practical matter, no expedited procedure will mean engaging the House leadership each time a rule is deemed important enough by a committee or group of members to seek speedy access to the floor”). 
resolution passes both houses of Congress, it is presented to the President for signing. ${ }^{65}$ The CRA drafters intended this structure to include both houses of Congress and the President so that it would meet the bicameralism and presentment requirements of the Constitution, which had thwarted an earlier congressional attempt to retain veto power over certain agency actions. ${ }^{66}$

Upon the enactment of a joint resolution against a federal agency rule, the rule will not take effect. ${ }^{67}$ If the rule has already taken effect by the time a joint resolution is enacted-for example, if the rule is not a major rule, or if the President has exercised the authority to override suspension of the rule's effective date ${ }^{68}$ - then it cannot continue in force. ${ }^{69}$ The effect of a joint resolution of disapproval is also retroactive: any regulation overridden by the CRA process is “treated as though [it] had never taken effect."70

${ }^{65} 5$ U.S.C. $\S 801(\mathrm{a})(3)(B)$. If the President vetoes a resolution disapproving of a major rule, the suspension of the effective date is extended, at a minimum, until the later of thirty days or the date that Congress votes and fails to override the President's veto. $I d$.

${ }^{66}$ U.S. CONST. art. I, § 7, cls. 2-3 (requiring, for a bill to become law, passage by both houses of Congress and either signing by the President or a presidential veto followed by a two-thirds congressional override in each house of Congress). Under these principles, the Supreme Court struck down section 224(c)(2) of the Immigration and Nationality Act, which allowed a single house of Congress to override the Attorney General's determination that deportation of an alien should be suspended. See INS v. Chadha, 462 U.S. 919 (1983), invalidating 8 U.S.C. $\S 1254(c)(2)$ (1982). Curiously, while the CRA was intended to give respect to the Constitution's bicameralism and presentment requirements, 142 ConG. REC. E575 (daily ed. Apr. 19, 1996) (speech of Rep. Hyde) (noting that, after Chadha, "[t]he one-house or two-house legislative veto . . . was thus voided" and the CRA procedure would require passage by both houses and presentment to the President); 142 CoNG. REC. S3683-84 (daily ed. Apr. 18, 1996) (joint statement of Sens. Nickles, Reid, and Stevens) (same), the 104th Congress shortly thereafter enacted the unconstitutional "line item veto" in violation of those very principles. See Line Item Veto Act of 1996, Pub. L. No. 104-130, 110 Stat. 1200 (codified as amended at 2 U.S.C. §§ 691-692 (Supp. II 1997)), invalidated by Clinton v. New York, 524 U.S. 417 (1998).

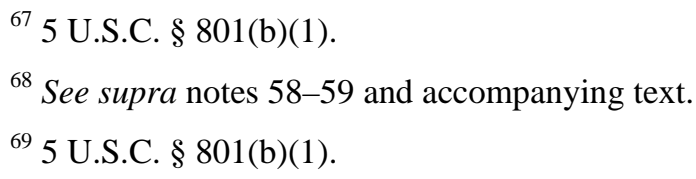

${ }^{70} \mathrm{Id}$. § 801(f). For a summary of the disapproval procedure created by the CRA and a discussion of its possible use as a tool to check midnight regulation, see Jerry Brito \& Veronique de Rugy, Midnight Regulations and Regulatory Review, 61 ADMIN. L. REV. 163, 189-90 (2009). 
The CRA places a further limitation on agency action following a successful veto, which is the focus of this Article. Not only does the regulation not take effect as submitted to Congress, but the agency may not be able to reissue another rule to replace the one vetoed. Specifically, the CRA provides:

A rule that does not take effect (or does not continue) under [a joint resolution of disapproval] may not be reissued in substantially the same form, and a new rule that is substantially the same as such a rule may not be issued, unless the reissued or new rule is specifically authorized by a law enacted after the date of the joint resolution disapproving the original rule. ${ }^{71}$

An agency's ability to promulgate certain rules after a veto thus turns on the CRA's meaning of “substantially the same form ....” We will discuss the range of scholarly and editorial interpretations of how ominously executive agencies should regard the prohibition against reissuance of "substantially similar” rules in Part III.B. But to foreshadow the main argument, we believe that most commentors have offered an unduly pessimistic reading of this provision. One of the most respected experts in administrative law, Professor Peter Strauss, testified before Congress a year after the enactment of the CRA that the "substantially similar" provision has a “doomsday effect.” Because, Strauss said, the provision precludes the affected agency from ever attempting to regulate in the same topical area, Congress may well have tied its own hands, and will refrain from vetoing rules altogether. ${ }^{72}$ Although we agree wholeheartedly ${ }^{73}$ with Strauss’ recommendation that Congress should amend the CRA to require a statement of the reasons for the initial veto, we simply observe here that events subsequent to his 1997 testimony demonstrate that Congress did not blanch from invoking a veto even when it was not primarily

${ }^{71} 5$ U.S.C. $\S 801(b)(2)$.

${ }^{72}$ Hearing Before the Subcomm. on Comm. \& Admin. Law of the H. Comm. on the Judiciary, 104th Cong. (Mar. 6, 1997) (statement of Peter L. Strauss). 
concerned about an agency exceeding its statutory authority: it overturned the OSHA

ergonomics rule in 2001 because of concern about excessive compliance costs and illusory riskreduction benefits. $^{74}$ Therefore, section $801(\mathrm{~b})(2)$ represents a very influential consequence of a veto power that Congress is clearly willing to use, and its correct interpretation is therefore of great importance to administrative law and process.

With very little evidence in the CRA's legislative history discussing this provision ${ }^{75}$ and only one instance in which the congressional veto has actually been carried out, ${ }^{76}$ the meaning of this crucial clause has not been clearly established. In the next several Parts, we will attempt to give the CRA's substantial similarity provision a coherent and correct meaning by interpreting it in the context of its legislative history, the political climate in which it was enacted and has been applied, and the broader administrative state.

\section{EXERCISE OF THE CONGRESSIONAL VETO}

The CRA procedure for congressional override of a federal regulation has only been used once. In 2001, when the Bush administration came into office, Republicans in Congress used the measure to strike down a workplace ergonomics regulation promulgated by the Occupational

${ }^{73}$ See infra Part VII.

${ }^{74}$ See infra Part VI.

${ }^{75}$ See 142 Cong. REC. E574-75 (daily ed. Apr. 19, 1996) (speech of Rep. Hyde) (noting that, although the measure had already been enacted into law, "no formal legislative history document was prepared to explain the [CRA]”); 142 Cong. REC. S3683 (daily ed. Apr. 18, 1996) (joint statement of Sens. Nickles, Reid, and Stevens) (same). rule).

${ }^{76}$ See infra Part II.A (discussing Congress's use of the veto in 2001 to disapprove of OSHA's ergonomics 
Safety and Health Administration (OSHA). ${ }^{77}$ The joint resolution generated much debate, in Washington and nationwide, over whether Congress should use the CRA procedure. ${ }^{78}$ This Part $^{2}$ discusses the joint resolution disapproving OSHA's ergonomics rule, and briefly notes some other instances in which the CRA has been brought up but not successfully executed. It then explores potential means by which the substantial similarity provision might be enforced.

\section{A. The OSHA Ergonomics Rule}

In 1990, Secretary of Labor Elizabeth Dole stated that ergonomic injuries were "one of the nation's most debilitating across-the-board worker safety and health issues,” and announced that the Labor Department under President George H.W. Bush was "committed to taking the most effective steps necessary to address the problem of ergonomic hazards.",79 As we will discuss briefly in Part VI, OSHA circulated in 1995 a complete regulatory text of an ergonomics rule, but it met with such opposition that it was quickly scuttled. Five years after abandoning the first ergonomics proposal, OSHA proposed a new section to Title 20 of the Code of Federal Regulations in order "to reduce the number and severity of musculoskeletal disorders (MSDs)

77 See Ergonomics Rule Disapproval, Pub. L. No. 107-5, 115 Stat. 7 (2001), invalidating Ergonomics Program; Final Rule, 65 Fed. Reg. 68,261 (proposed Nov. 14, 2000).

${ }^{78}$ Compare Robert A. Jordan, Heavy Lifting Not W’s Thing, Boston GLOBE, Mar. 11, 2001, at E4 (arguing that President Bush's support of the joint resolution to overturn OSHA's labor ergonomics rule sends the message, "I do not share-or care about-your pain”), with Editorial, Roll Back the OSHA Work Rules, CHI. TRIB., Mar. 6, 2001, at N14 (calling the ergonomics rule "bad rule-making” and arguing that Congress should "undo it”). See generally 147 CONG. REC. H684-708 (daily ed. Mar. 7, 2001) (chronicling the floor debates in the House); 147 ConG. REC. S1831-88 (daily ed. Mar. 6, 2001) (chronicling the floor debates in the Senate).

${ }^{79}$ Press Release, Elizabeth H. Dole, Secretary, Dep’t of Labor, Secretary Dole Announces Ergonomics Guidelines to Protect Workers from Repetitive Motion Illnesses/Carpal Tunnel Syndrome 1 (Aug. 30, 1990). 
caused by exposure to risk factors in the workplace." ${ }^{\prime 80}$ The regulation would, among other things, require employers to provide employees with certain information about ergonomic injuries and MSDs and implement "feasible" controls to reduce MSD hazards if certain triggers were met. ${ }^{81}$ OSHA published the final rule in the Federal Register during the lame-duck period of the Clinton administration, and it met strong opposition from Republicans and pro-business interest groups.

After the 107th Congress was sworn in, Senate Republicans led the charge against the ergonomics rule and proposed a joint resolution to disapprove of the regulation pursuant to the CRA. ${ }^{82}$ Opponents of the OSHA regulation argued that it was the product of a flawed, lastminute rulemaking process in the outgoing Clinton administration. ${ }^{83}$ Although the Department of Labor had been attempting to develop an ergonomics program for at least the previous ten years, ${ }^{84}$ the opponents called this particular rule "a regulation crammed through in the last couple of days of the Clinton administration" as a "major gift to organized labor ....”85 Senator Mike Enzi of Wyoming argued that the proposed regulation was not published in the Federal Register until "a mere 358 days before [OSHA] made it the law of the land, one quarter of the time they

${ }^{80}$ Ergonomics Program; Proposed Rule, 64 Fed Reg. 65,768-66,078 (proposed Nov. 23, 1999); see also Final Rule, 65 Fed. Reg. 68,261, 68,846 (proposed Nov. 14, 2000).

${ }^{81}$ Ergonomics Program; Final Rule, 65 Fed. Reg. at 68,847, 68,850-51.

${ }^{82}$ See S.J. Res. 6, 107th Cong. (2001) (enacted).

${ }^{83}$ See, e.g., 147 Cong. REC. S1832 (daily ed. Mar. 6, 2001) (statement of Sen. Jeffords) (“[T]he ergonomics rule certainly qualifies as a 'midnight' regulation.”).

${ }^{84}$ See Ergonomics Program; Final Rule, 65 Fed. Reg. at 68,264 (presenting an “OSHA Ergonomics Chronology"); see also supra note 79 and accompanying text (noting that Department of Labor's commitment in 1990 to address ergonomic injuries).

85147 Cong. REC. S1833-34 (daily ed. Mar. 6, 2001) (statement of Sen. Nickles). 
typically take. ${ }^{„ 86}$ He further implied that OSHA ignored criticisms received during the notice and comment period, and instead relied on "hired guns" to provide information and tear apart witness testimony against the rule. ${ }^{87}$

This allegedly flawed and rushed procedure, OSHA's opponents argued, coupled with an overly aggressive posture toward the regulated industries, ${ }^{88}$ led to an inefficient and unduly burdensome rule. Congressional Republicans and other critics seemed unconvinced by the agency's estimate of the costs and benefits. OSHA estimated that the regulation would cost $\$ 4.5$ billion, while others projected that it could cost up to $\$ 100$ billion—Senator Don Nickles of Oklahoma noted this wide range of estimates and said, "There is no way to know how much this [rule] would cost." ${ }^{\text {} 99}$ Democrats, however, argued that the rule was not wasteful. Senator Edward Kennedy of Massachusetts said that the ergonomics rule was "flexible and cost-effective for businesses, and . . o overwhelmingly based upon scientific evidence."90 The rule’s proponents also emphasized its benefits, arguing that the rule’s true cost of $\$ 4.5$ billion would be more than offset by a savings of " $\$ 9.1$ billion annually ... recouped from the lost productivity, lost tax payments, administrative costs, and workers comp." ${ }^{\text {11 }}$ Critics argued that these benefits

${ }^{86} 147$ Cong. REC. S1839 (daily ed. Mar 6, 2001) (statement of Sen. Enzi).

${ }^{87} I d$. (estimating that "close to 2 million pages" of materials were submitted during to OSHA during the public comment period, yet "there were only 94 days between the end of the public comment period and the date of the OSHA-published rule”).

${ }^{88}$ See, e.g., Lisa Junker, Marthe Kent: A Second Life in the Public Eye, , THE SyNERGist, May 15, 2000, at 28, 36, (quoting former OSHA Director of Safety Standards, Marthe Kent, as saying: "I was born to regulate. I don't know why, but that's very true. So long as I'm regulating, I'm happy. ... I think that's really where the thrill comes from. And it is a thrill; it's a high.”).

89147 Cong. REC. S1834 (daily ed. Mar. 6, 2001) (statement of Sen. Nickles); see also Editorial, supra note 78 ("Although [OSHA] puts the price tag on its rules at $\$ 4.5$ billion, the Economic Policy Foundation gauges the cost to business at a staggering $\$ 125.6$ billion.”).

90147 ConG. REC. S1835 (daily ed. Mar. 6, 2001) (statement of Sen. Kennedy).

${ }^{91} 147$ Cong. ReC. S1843 (daily ed. Mar. 6, 2001) (statement of Sen. Wellstone). 
were overstated as businesses were naturally becoming more ergonomically friendly on their own. $^{92}$ Democrats also noted scientific evidence favoring the rule, including two reports by the National Academy of Sciences (NAS) and the Institute of Medicine reporting the enormous costs of work-related ergonomic injuries. ${ }^{93}$ But critics cited reports in their favor, ${ }^{94}$ and responded that the NAS report did not endorse the rule and could not possibly have shaped it, as the report was not released until after OSHA went forward with the regulation. ${ }^{95}$

Following expedited debate in Congress in which the legislators argued about the costs and benefits of the OSHA rule, both houses passed the joint resolution in March $2001 .^{96}$ When President Bush signed the joint resolution into law, he emphasized the need for "an understanding of the costs and benefits” and his administration's intent to continue to “pursue a comprehensive approach to ergonomics ....”97 However, there has never been an authoritative interpretation of the joint resolution's effect on OSHA's ability to promulgate ergonomics rules in the future without specific congressional authorization.

92147 CONG. REC. S1832 (daily ed. Mar. 6, 2001) (statement of Sen. Jeffords). Of course, if a marketdriven move toward ergonomically friendly business meant that the benefits of OSHA's rule were overstated, then its costs must have been simultaneously overstated as well.

${ }^{93}$ See 147 CONG. REC. S1846 (daily ed. Mar. 6, 2001) (statement of Sen. Dodd) (citing a report finding that "nearly 1 million people took time from work to treat or recover from work-related ergonomic injuries" and that the cost was “about $\$ 50$ billion annually”).

${ }^{94}$ See 147 CONG. REC. S1849 (daily ed. Mar. 6, 2001) (statement of Sen. Hutchinson) (citing a report that "shows that the cost-to-benefit ratio of this rule may be as much as 10 times higher for small businesses than for large businesses).

95 See 147 CONG. REC. H685 (daily ed. Mar. 7, 2001) (statement of Rep. Boehner) (“OSHA completed its ergonomics regulation without the benefit of the National Academy study.”).

${ }^{96}$ See Ergonomics Rule Disapproval, Pub. L. No. 107-5, 115 Stat. 7 (2001), invalidating Ergonomics Program; Final Rule, 65 Fed. Reg. 68,261 (proposed Nov. 14, 2000); 147 CoNG. REC. H707-08 (daily ed. Mar. 7, 2001) (recording the House roll call vote of 223-206, with 4 Representatives not voting); 147 CONG. REC. S188788 (daily ed. Mar. 6, 2001) (recording the Senate roll call vote of 56-44).

${ }^{97}$ Statement on Signing Legislation to Repeal Federal Ergonomics Regulations, 37 WEEKLY COMP. PRES. DoC. 477 (Mar. 20, 2001). 


\section{B. Midnight Regulations and Other Threats to Use the CRA}

The repeal of the OSHA ergonomics regulation has so far been the only instance in which the CRA has been successfully used to veto a federal regulation. However, the option of congressional repeal of rules promulgated by federal agencies has been considered in several other arenas, and in some instances threats by legislators to call for a CRA veto have led to a type of "soft veto" in which the agency responds to the threat by changing its proposed regulation. This has surfaced often, though not always, in the context of possibly repealing socalled "midnight regulations." 98

Some Republican lawmakers argued that the OSHA ergonomics standard circumvented congressional oversight because it was finalized in the final weeks of the Clinton administration. ${ }^{99}$ Years later, these same arguments were echoed by the Obama administration and some Democrats in the 111th Congress with respect to other rules. As the Bush administration left office in January 2009, it left behind several last-minute regulations, including rules that would decrease protection of endangered species, allow development of oil shale on some federal lands, and open up oil drilling in the Utah wilderness. ${ }^{100}$ The Bush administration also left behind a "conscientious objector" regulation that would allow certain healthcare

${ }^{98}$ See Jack M. Beermann, Essay, Combating Midnight Regulation, 103 Nw. U. L. REv. ColloQuy 352, 352 n.1 (2009) (“'Midnight regulation' is loosely defined as late-term action by an outgoing administration.”). Colloquially, the term is usually used when the White House changes parties.

${ }^{99}$ See supra notes 83-87 and accompanying text.

${ }^{100}$ See, e.g., Stephen Power, Obama Blocks Bush’s Endangered-Species Rule, WALL St. J., Mar. 3, 2009, at A4, available at http://online.wsj.com/article/NA_WSJ_PUB:SB123609338658819219.html (noting executive and administrative decisions to "shelve" these rules). 
providers to refuse to administer abortions or contraception. ${ }^{101}$ Congressional Democrats brought up the CRA as an option for repealing the Bush administration's midnight regulations, while the Obama administration searched for an executive strategy for ending the regulations. ${ }^{102}$ Although the CRA may be at its most useful when there is a significant realignment in party control over the legislative and executive branches (as occurred in 2001 and 2009), ${ }^{103}$ the Democrats of the 111th Congress did not use the CRA to achieve their goal of overturning the Bush administration's regulations — in the end, the Obama administration used executive procedures. $^{104}$

Not all threats to use the CRA have occurred immediately following a party change, however. In early 2010, one year after President Obama’s inauguration, Senator Lisa Murkowski of Alaska considered proposing a resolution to disapprove of EPA's “endangerment

${ }^{101}$ See Jennifer Lubell, Conscientious Objectors; Obama Plan to Rescind Rule Draws Catholic Criticism, Modern HeAlthCARE, Mar. 23, 2009 (discussing the Obama administration's plans to prevent the Bush administration's “conscientious objector” rule from going into effect); Charlie Savage, Democrats Look for Ways to Undo Late Bush Administration Rules, N.Y. TimEs, Jan. 12, 2009, at A10 ("Democrats are hoping to roll back a series of regulations issued late in the Bush administration that weaken environmental protections and other restrictions.").

102 See Peter Nicholas \& Christi Parsons, Obama Plans a Swift Start, L.A. TiMES, Jan. 20, 2009, at A1 (reporting that "Obama aides have been reviewing the so-called midnight regulations" and noting that "Obama can change some Bush policies through executive fiat”); Savage, supra note 101, at A10 (reporting that "Democrats ... are also considering using the Congressional Review Act of 1996” to overturn some Bush administration regulations).

103 See Brito \& de Rugy, supra note 70, at 190 ("[T]he CRA will only be an effective check on midnight regulations if the incoming president and the Congress are of the same party. If not, there is little reason to expect that the Congress will use its authority under the CRA to repeal midnight regulations. Conversely, if the president is of the same party as his predecessor and the Congress is of the opposite party, it is likely that the new president will veto a congressional attempt to overturn his predecessor's last-minute rules.” (footnote omitted)). But see Rosenberg, supra note 64 (pointing out flaws in the CRA and proposing a new scheme of congressional review of federal regulation).

${ }^{104}$ See, e.g., Rescission of the Regulation Entitled "Ensuring That Department of Health and Human Services Funds Do Not Support Coercive or Discriminatory Policies or Practices in Violation of Federal Law”; Proposal, 74 Fed. Reg. 10,207 (proposed Mar. 10, 2009) (to be codified at 40 C.F.R. pt. 88) (rescinding the Bush administration’s “conscientious objector” rule). 
finding” that greenhouse gases threaten the environment and human health. ${ }^{105}$ (Note, however, that it is unclear that an agency "finding" is a sufficiently final agency action for a CRA veto. Nor is it clear that a joint resolution of disapproval may be inserted as part of a large bill, as Murkowski considered. ${ }^{106}$ ) Senator Murkowski’s idea never came to fruition.

\section{Enforcement of the Substantial Similarity Provision}

Since there has never yet been an attempt by an agency to reissue a rule following a CRA veto, there remains ambiguity not only over what kinds of rules are barred, but how any restrictions would be enforced. In this Section, we briefly discuss three possible ways the "substantially the same” provision may affect agency action: one administrative response, one legislative, and one judicial.

One possible means of application of the substantial similarity provision begins in the executive branch, most likely within the administrative department whose regulation has been vetoed. With the threat of invalidation hanging overhead, an agency may be deterred from promulgating regulations within a certain area for fear of having its work nullified—or worse, having ruined for posterity the ability to regulate in a given area (if it interprets the CRA ominously). In other words, agencies might engage in a sort of "self-censorship" that itself enforces the CRA. Indeed, the continuous absence of ergonomics from the regulatory agenda for an entire decade following the veto of OSHA's rule — and well into the Obama administration-

${ }^{105}$ See Editorial, Ms. Murkowski’s Mischief, N.Y. TimEs, Jan. 18, 2010.

${ }^{106}$ Cf. 5 U.S.C. § 802(a) (2006) (setting forth the exact text to be used in a joint resolution of disapproval). Murkowski intended to insert the resolution into the bill lifting the debt ceiling. See Editorial, supra note 105. 
arguably provides evidence of such self-censorship. In prepared testimony before a Senate subcommittee on appropriations, Secretary of Labor Elaine Chao testified that, due to the exercise of the veto, the Department of Labor would need to work with Congress to determine what principles to apply to any future regulation in the ergonomics field. She did not want to “expend valuable_—and limited_resources on a new effort” if another regulation would be invalidated as substantially similar. ${ }^{107}$

In addition to agency self-censorship, there is, of course, a potential legislative application of the substantial similarity provision. If an agency were to reissue a vetoed rule "in substantially the same form," then Congress could use the "substantially the same" provision as an additional justification for enacting another joint resolution, perhaps complementing its objection to the substance of the new rule, but perhaps using it to bypass a discussion of the merits. For example, if OSHA reissued an ergonomics rule that members of Congress thought was substantially similar to the Clinton administration rule, then they might be motivated to repeal the rule simply because they would see the new rule as outside the law, and a disrespect to their prior action under the CRA. Of course, as with the ergonomics rule, the notion that an agency is acting outside its authority may be considered merely a factor among othersprocedural, cost-benefit related, and even political—in determining whether to strike down an agency rule. But a congressional belief that an agency is reissuing a rule in violation of the CRA

${ }^{107}$ Departments of Labor, Health and Human Services, and Education, and Related Agencies Appropriations for Fiscal Year 2002: Hearing on H.R. 3061/S. 1536 Before a Subcomm. of the S. Comm. on Appropriations, 107th Cong. 72 (2001) (statement of Elaine L. Chao, Secretary, United States Department of Labor). However, Secretary Chao had promised immediately before the veto that she would do exactly the opposite, and treat a CRA action as an impetus to reissue an improved rule. See Letter from Elaine L. Chao, Secretary, Dep't of Labor, to Arlen Specter, Chairman, Subcomm. on Labor, Health \& Human Servs., Educ., Comm. on Appropriations, U.S. Senate (Mar. 6, 2001) (promising to take future action to address ergonomics), reprinted in 147 CONG. REC. S1859, exhibit 1 (daily ed. Mar. 6, 2001) (statement of Sen. Specter). For a discussion of the curious about-faces in statements by members of Congress immediately before and after the veto, see infra Part III.B. 
may cut in favor of enacting a second joint resolution of disapproval, even if certain members of

Congress would not be inclined to veto the rule on more substantive grounds. Indeed, this could even turn Congress's gaze away from the rule’s substance entirely—a sort of "us against them" drama might be played out in which opponents could use the alleged "circumvention" as a means to stir up opposition to a rule that the majority might find perfectly acceptable if seeing it $d e$ novo.

The judiciary might also weigh in on the issue. If an agency were to reissue a rule that is substantially similar to a vetoed rule, and somehow Congress chose not to exercise its power of veto under the CRA, then a regulated party might convince the courts to strike down the rule as outside of the agency's statutory authority. ${ }^{108}$ There appear to be two primary ways in which this would be possible. First, a party might raise invalidity as a defense if an agency were to try enforcing a rule it did not have authority to promulgate under the CRA. The defendant in the administrative proceedings could appeal agency enforcement of the rule to the federal courts

${ }^{108}$ Although judicial review of CRA-related activity is significantly limited, see 5 U.S.C. § 805 (2006) ("No determination, finding, action, or omission under this chapter shall be subject to judicial review."), the legislative record makes clear that "a court with proper jurisdiction may review the resolution of disapproval and the law that authorized the disapproved rule to determine whether the agency has the legal authority to issue a substantially different rule.” 142 Cong. REC. S3686 (daily ed. Apr. 18, 1996) (statement of Sen. Nickles). Indeed, the CRA prohibits a court only from inferring the intent of Congress in omitting to enact a joint resolution of disapproval, implying that courts should (1) consider congressional intent in considering enacted resolutions, and (2) not infer substantial dissimilarity from Congress' failure to veto a second rule. See 5 U.S.C. § 801(g) ("If the Congress does not enact a joint resolution of disapproval under section 802 respecting a rule, no court or agency may infer any intent of the Congress from any action or inaction of the Congress with regard to such rule, related statute, or joint resolution of disapproval.”); see also 142 CoNG. REC. S3686 (daily ed. Apr. 18, 1996) (statement of Sen. Nickles) (referring to Section 801(g) and noting that "[t]he limitation on judicial review in no way limits a court from determining whether a rule is in effect”). While some may call into question the constitutionality of such strong limits on judicial review, the CRA drafters' constitutional argument defending the provisions suggests that the limits are meant to address procedure. See id. ("This ... limitation on the scope of judicial review was drafted in recognition of the constitutional right of each House of Congress to 'determine the Rules of its Proceedings,' which includes being the final arbiter of compliance with such rules.” (citing U.S. ConsT., art. I, § 5, cl. 2) (citation omitted)). Thus, since a court may rule upon whether a rule is in effect, yet lacks the power to weigh Congress's omission of a veto against a finding of substantial similarity, a court could conduct its own analysis to determine whether a non-vetoed second rule is substantially similar and hence invalid. 
under Chapter 7 of the APA, and a court might then strike down the regulation as a violation of the substantial similarity provision. ${ }^{109}$ But a regulated party need not wait until an agency attempts to enforce the rule in order to raise a challenge - as a second option, one may go on the offensive and bring suit for declaratory judgment or injunctive relief in order to prevent the agency from enforcing the rule in the first place. ${ }^{110}$ In either of these situations, assuming a justiciable case or controversy under Article III, ${ }^{111}$ a federal court would need to interpret the CRA in order to determine whether the reissued rule is substantially similar to a vetoed rule and thus invalid.

Since such a lawsuit has not yet been litigated in the federal courts, there is not yet an authoritative interpretation of the CRA to guide agency rulemaking in an efficient manner. ${ }^{112}$ Where an agency does not wish to risk invalidation of a rule that merely may skirt the outer margins of substantial similarity (whatever those may be), the effect of the CRA may be to overdeter agency action via "self-censorship" even where its regulation may be legally valid in actuality. Until the federal courts provide an authoritative interpretation of the CRA, those outer margins of substantial similarity are quite large. ${ }^{113}$ For this reason, it is important to provide a

${ }^{109}$ See 5 U.S.C. § 702 (2006) (conferring a right of judicial review to persons "suffering legal wrong because of agency action”); id. § 706(2)(C) (granting courts the authority to strike down agency action that is "in excess of statutory jurisdiction, authority, or limitations, or short of statutory right”); see also id. § 704 (requiring that an aggrieved party exhaust its administrative remedies before challenging a final agency action in federal court).

${ }^{110}$ See, e.g., Babbitt v. Sweet Home Chapter of Cmtys. for a Great Or., 515 U.S. 687 (1995) (entertaining a declaratory relief action brought by parties challenging a regulation promulgated by the Department of Interior under the Endangered Species Act).

${ }^{111}$ U.S. CONST. art. III, § 2 (granting the federal courts jurisdiction only over “cases” and “controversies”); see also Lujan v. Defenders of Wildlife, 504 U.S. 555 (1992) (explaining the requirement of plaintiff standing); O’Shea v. Littleton, 414 U.S. 488 (1974) (requiring that the plaintiff's case be ripe for adjudication).

${ }^{112}$ See Marbury v. Madison, 5 U.S. (1 Cranch) 137, 177 ("It is emphatically the province and duty of the judicial department to say what the law is.”).

${ }^{113}$ See infra Part III (providing a spectrum of possible interpretations, and noting the vastly different interpretations of the substantial similarity provision during the debates over the ergonomics rule). 
workable and realistic interpretation of the CRA in order to guide agency action and avoid overdeterrence. It is also important to set boundaries that relate to the problem of agency inaction - we do not want agencies hiding behind the CRA as an excuse not to do anything in an area where the public expects some action and where Congress did not intend to block all rulemaking in the area.

In the next two Parts, we will attempt to reconcile the vast spectrum of possible "substantial similarity" interpretations with the political and legislative history of the CRA and the joint resolution overturning the OSHA ergonomics rule with background principles of CBA and administrative law.

\section{The Spectrum OF INTERPRETATIONS OF “SubStaNTIALly SimilaR”}

In this Part, we develop seven possible interpretations of the key term "substantially similar," demonstrate that interpretations offered by partisans during the ergonomics debate should be uniformly ignored as posturing, and suggest that interpretations offered after the ergonomics veto are too pessimistic.

\section{A. Hierarchy of Possible Interpretations}

Rather than constructing a definition of "substantially the same" from first principles, we will ground this discussion with reference to the spectrum of plausible interpretations of that key phrase, arrayed in ascending order from the least troublesome to the issuing agency to the most daunting. We use this device not to suggest that the center of gravity in the struggle of 
competing ideologies in Congress at the time the CRA was enacted should point the way towards a particular region of this spectrum, but rather to erect some markers that can be rejected as implausible interpretations of "substantially the same" and thereby help narrow this range. Although we will support our interpretation with reference to specific items in the legislative history of the CRA, starting out with this hierarchy also allows us to focus on what Congress could have made much more explicit in its attempt to prevent agencies from reissuing rules that would force duplicate congressional debate.

We can imagine at least seven different levels of stringency that Congress could plausibly have chosen when it wrote the CRA and established the "substantially the same" test to govern the reissuance of related rules:

\section{Interpretation 1: An identical rule can be reissued if the agency asserts that external}

conditions have changed. A reissued rule only becomes "substantially the same," in any sense that matters, if Congress votes to veto it again on these grounds. Therefore, an agency could simply wait until the makeup of Congress changes, or the same members indicate a change of heart about the rule at hand or about regulatory politics more generally, and reissue an identical rule-while claiming that although the regulation was doubtless in "substantially the same form," the effect of the rule is now substantially different from what it would have been the first time around. If Congress chooses to allow the rule to take effect, then the statutory meaning of "form" must have included not only the words on the pages of the rule, but the results of the rule.

\section{Interpretation 2: An identical rule can be reissued if external conditions truly have}

changed. We will discuss this possibility in detail in Part V. This interpretation of "substantially the same" recognizes that the effects of regulation—or the estimates of those effects — can change over time even if the rule itself does not change. Our understanding of the 
science (economics) behind a rule can change our understanding of its benefits (costs), or those benefits and costs themselves can change as technologies improve or new hazards emerge. For example, a hypothetical FAA rule banning smoking on airliners might have seemed draconian if proposed in 1960, given the understanding of the risks of second-hand smoking at the time, but it was clearly received much differently when issued thirty years later. ${ }^{114}$ Safety technologies such as antilock brake systems that would have been viewed as experimental and prohibitively expensive when first developed came to be viewed as extremely cost-effective when their costs decreased with time. In either type of situation, an identical rule might become "substantially different" not because the vote count had changed, but because the same regulatory language had evolved a new meaning, and then Congress might welcome another opportunity to evaluate the costs and benefits.

Interpretation 3: The reissued rule must be altered so as to have significantly greater benefits and/or significantly lower costs than the original rule. Under this interpretation, the notion of "similar form" would not be judged via a word-by-word comparison of the two versions, but by a common-sense comparison of the stringency and impact of the rule. We will discuss in Part IV a variety of reasons why we believe Congress intended that the currency for judging "similarity" should be costs and benefits, rather than the regulatory text per se or the extent to which a reissued rule contains wholly different provisions or takes a different approach. At this point, it should suffice to point out that as a practical matter, two versions of a regulation that have vastly different impacts on society might contain 99.99 percent or more of their individual words in common, and thus be almost identical in "form" if that word was used in its

\footnotetext{
${ }^{114}$ Prohibition Against Smoking: Final Rule, 55 Fed. Reg. 8364 (proposed March 7, 1990).
} 
most plebian sense. An OSHA rule requiring controls on a toxic substance in the workplace, for example, might contain thousands of words describing engineering controls, exposure monitoring, recordkeeping, training, issuance of personal protective equipment, and other elements, all triggered when the concentration of the contaminant exceeded some numerical limit. If OSHA reissued a vetoed toxic-substance rule with one single word changed (the number setting the limit), the costs and burdens could drop precipitously. We suggest it would be bizarre to constrain the agency from attempting to satisfy congressional concerns by fundamentally changing the substance and import of a vetoed rule, merely because doing so might affect only a small fraction of the individual words in the regulatory text. ${ }^{115}$

\section{Interpretation 4: In addition to changing the overall costs and benefits of the rule,}

\section{the agency must fix all of the specific problems Congress identified when it vetoed the rule.}

This interpretation would recognize that despite the paramount importance of costs, benefits, and stringency, Congress may have reacted more to specific aspects of the regulation. Perhaps it makes little sense for an agency to attempt to reissue a rule that is substantially different in broad terms, but that "pushes the same buttons" with respect to the way it imposes costs (of whatever magnitude), or treats the favored sectors or constituents that it doesn't exempt. However, as we will discuss in Part IV.B, the fact that Congress chose not to accompany statements of disapproval with any language explaining the consensus of what the objections were may make it inadvisable to require the agency to fix problems that were never formally defined, and that may not even have been seen as problems by more than a few vocal Representatives.

\footnotetext{
${ }^{115}$ It is even conceivable that a wholly identical regulatory text could have very different stringency, if the accompanying Preamble made clear that it would be enforced in a different way than the agency had intended when it first issued the rule (or that Congress had misinterpreted when it vetoed the rule).
} 


\section{Interpretation 5: In addition to changing the costs and benefits and fixing specific}

problems, the agency must do more to show it has "learned its lesson.” This interpretation would interpret "substantially the same form” in an expansive way befitting the colloquial use of the word "form" as more than, or even perpendicular to, substance. In other words, the original rule deserved a veto because of how it was issued, not just because of what was issued, and the agency needs to change its attitude, not just its output. This interpretation comports with Senator Enzi's view of why the CRA was written, as he expressed during the ergonomics floor debate: "I assume that some agency jerked the Congress around, and Congress believed it was time to jerk them back to reality. Not one of you voted against the CRA."116 If the CRA was created as a mechanism to assert the "reality" of congressional power, then merely fixing the regulatory text may not be sufficient to avoid repeating the same purported mistakes that doomed the rule upon its first issuance.

Interpretation 6: In addition to the above, the agency must devise a wholly different regulatory approach if it wishes to regulate in an area Congress has cautioned it about. This would interpret the word "form" in the way that scholars of regulation use to distinguish fundamentally different kinds of regulatory instruments - if the vetoed rule was, for example, a specification standard, the agency would have to reissue it as a performance standard in order to devise something that was not in "substantially the same form." An even more restrictive reading would divide "form” into the overarching dichotomy between command-and-control and voluntary (or market-based) designs: if Congress nixed a "you must” standard, the agency

116147 CONG. REC. S1837 (daily ed. Mar. 6, 2001) (statement of Sen. Enzi). 
would have to devise a "you may" alternative to avoid triggering a "substantially similar” determination.

\section{Interpretation 7: An agency simply cannot attempt to regulate (in any way) in an}

area where Congress has disapproved of a specific regulation. This most daunting interpretation would take its cue from the clause that follows the "same form” prohibition: "unless the reissued or new rule is specifically authorized by a law enacted after the date of the joint resolution disapproving the original rule." Such a reading could have been motivating the dire pronouncements of congressional Democrats who argued, as did Senator Russ Feingold of Wisconsin, that "a vote for this resolution is a vote to block any Federal ergonomics standard for

the foreseeable future." ${ }^{117}$ However, we will argue below that it is clear that Congress meant this clause only to apply in the rare cases where the organic statute only allowed the exact rule that the agency brought forward, and thus the veto created a paradox.

\section{B. How Others Have Interpreted "Substantially the Same"}

By far the majority of all the statements interpreting the meaning of "substantially the same” were uttered by members of Congress during the floor debate over the OSHA ergonomics standard. None of these statements occupied the wide middle ground within the spectrum of possible interpretations presented above. Rather, at one extreme were many statements trivializing the effect of the veto, such as "the CRA will not act as an impediment to OSHA should the agency decide to engage in ergonomics rulemaking.” The members who disagreed with this sanguine assessment did so in stark, almost apocalyptic terms, as in "make no mistake 
about the resolution of disapproval that is before us. It is an atom bomb for the ergonomics rule. ... [U]ntil Congress gives it permission, OSHA will be powerless to adopt an ergonomics rule.”

Surely the Democrats in Congress prefer an interpretation of legislative control over the regulatory system that defers maximally to the executive agencies, allowing them to regulate with relatively few constraints or delays, while Republicans favor an interpretation that gives Congress the power to kill whole swaths of regulatory activity "with extreme prejudice.” But in both cases, what they want the CRA to mean in general is the opposite of what they wanted their colleagues to think it meant in the run-up to a vote an a specific resolution of disapproval! Hence the fact that the first quote above, and dozens like it, came not from the left wing but from Republican James Jeffords of Vermont ${ }^{118}$; whereas the “atom bomb” and similarly bleak interpretations of the CRA came from Democrats such as Edward Kennedy of Massachusetts. ${ }^{119}$ Clearly, both the trivialization of a possible veto by those hoping to convince swing voters that their disapproval was a glancing blow, as well as the statements cowering before the power of the CRA by those hoping to dissuade swing voters from "dropping the bomb," should not be taken at face value, and should instead be dismissed as posturing to serve an expedient purpose.

117147 CoNG. REC. S1874 (daily ed. Mar. 6, 2001) (statement of Sen. Feingold).

118147 CONG. REC. S1833 (daily ed. Mar. 7, 2001) (statement of Sen. Jeffords)

119147 Cong. REC. S1836 (daily ed. Mar. 7, 2001) (statement of Sen. Kennedy). This pattern was also clearly evident in the House floor debate on ergonomics. Consider, for example, this sanguine assessment from a strident opponent of the OSHA rule, Republican Representative Roy Blunt: "When we look at the legislative history of the Congressional Review Act, it is clear that this issue can be addressed again. . . . [T] cannot be sent back essentially with one or two words changed. [But,] this set of regulations can be brought back in a much different and better way.” 147 Cong. Rec. H686 (daily ed. Mar. 7, 2001) (statement of Rep. Blunt). At the opposite end of the spectrum were proponents of ergonomics regulation such as Democratic Representative Rob Andrews: "Do not be fooled by those who say they want a better ergonomics rule, because if this rule passes, [t]his sends ergonomics to the death penalty.” 147 Cong. Rec. H688 (daily ed. Mar. 7, 2001) (statement of Rep. Andrews). 
Indeed, when the smoke cleared after the ergonomics veto, the partisans went back to their usual stances.

The set of less opportunistic interpretations of "substantially the same," on the other hand, has a well-defined center of gravity. Indeed, most legal and political science scholars, as well as experts in OSHA rulemaking, seem to agree that a veto under the CRA is at least a harsh punishment, and perhaps a death sentence. For example, Charles Tiefer describes the "substantially the same" provision as a "disabling of the agency from promulgating another rule on the same subject." ${ }^{\text {220 }}$ Morton Rosenberg, the resident expert on the CRA at the Congressional Research Service, wrote after the ergonomics veto that "substantially the same" is ambiguous, but he only reached a sanguine conclusion about one narrow aspect of it: an agency does not need express permission from Congress to reissue a "substantially different" rule when it is compelled to act by statutory or judicial deadline. ${ }^{121}$ He concluded most generally that whatever the correct legal interpretation, "the practical effect ... may be to dissuade an agency from

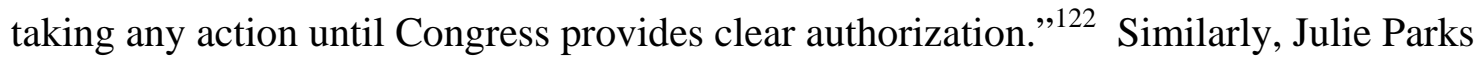
criticized section 801(b)(2) as “unnecessarily vague," but concluded that it at least "potentially withdraws substantive authority for OSHA issue any regulation concerning ergonomics."123

${ }^{120}$ Charles Tiefer, How to Steal a Trillion: The Uses of Laws about Lawmaking in 2001, J.L. \& PoL., Summer 2001, 409, at 476.

${ }^{121}$ Morton Rosenberg, Am. L. Div., CRS Rep. No. RL30116, Congressional Review of Agency RULEMAKING: AN UPDATE AND AsSESSMENT AFTER NULLIFICATION OF OSHA’s ERGONOMICS STANDARD 23 (2003).

${ }^{122} I d$.

${ }^{123}$ Julie A. Parks, Comment, Lessons in Politics: Initial Use of the Congressional Review Act, 55 ADMIN. L. REV. 187, 200 (2003) (emphasis added); see also Stuart Shapiro, The Role of Procedural Controls in the Ergonomics Rulemaking, PUB. AdMIN. REV., July-Aug. 2007, at 688,, 696 (concluding that "attempts to create an ergonomics regulation had effectively ended" with the 2001 veto, because of the language of section 801(b)(2)). 
Advocates for strong OSHA regulation, who presumably would have no interest in demonizing the CRA after the ergonomics veto had already passed, nevertheless also take a generally somber view. Vernon Mogensen interprets "substantially the same” such that "the agency that issued the regulation is prohibited from promulgating in the same area again without Congressional authorization. In fact, it would be virtually impossible for OSHA to reissue an ergonomics standard of commensurate strength in the prevailing antiregulatory political climate."124 A.B. (Butch) de Castro-who helped write the ergonomics standard while an OSHA staff member-similarly opined in 2006 that “OSHA is barred from pursuing development of another ergonomics standard unless ordered so by Congress.”125 Parks interviewed Charles Jeffress, who was the OSHA Assistant Secretary who "bet the farm" on the ergonmics rule, in 2002, and he reportedly said (presumably with chagrin) that "OSHA does not have the authority to issue another ergonomics rule, because the substantially similar language is vague and ambiguous."

As we will argue in detail below, we believe that all of these pronouncements ascribe to Congress more power to preemptively bar reissued regulations than the authors of the CRA intended, and certainly more anticipatory power than Congress should be permitted to wield.

${ }^{124}$ Vernon Mogensen, The Slow Rise and Sudden Fall of OSHA's Ergonomics Standard, WORKINGUSA, Fall 2003, at 54, 72.

${ }^{125}$ A.B. de Castro, Handle with Care: The American Nurses Association's Campaign to Address WorkRelated Musculoskeletal Disorders, 4 CliniCAl ReV. Bone \& Mineral MetABolism 45, 50.

${ }^{126}$ Parks, supra note 123, at 200. Note that Jeffress' statement that the language is "vague and ambiguous" expresses uncertainty and risk aversion within the agency, rather than a confident stance that issuance of another ergonomics standard would actually be illegal. See also supra Part II.C (noting agency self-censorship as one means of enforcing the CRA's substantial similarity provision). 


\section{Why “SubStANTIALly the SAME” SHOUld Not Be INTERPRETED OMinOUSLY}

Courts have not yet had occasion to interpret the CRA's substantial similarity provision, so the true future effects of a joint resolution repealing a regulation remain unknown. In this Part, we argue that, so long as the rule as reissued makes enough changes to alter the cost-benefit ratio in a significant and favorable way (and, we recommend, as long as the issuing agency also corrects any procedural flaws that Congress deplored as essentially "arbitrary and capricious"), the purposes of the CRA will be served and the new rule should not be barred as "substantially the same” (although it would not be immunized against a second veto on new substantive grounds).

We find four sets of reasons for this interpretation of the substantial similarity provision. First, the legislative history—both in the mid-1990s when the Republicans took control of Congress and enacted the CRA, and when Congress struck down the OSHA ergonomics rule in 2001—indicates that CBA and risk assessment were the intended focus. ${ }^{127}$ Congress wanted more efficient regulations, and requiring an agency to go back and rewrite rules that failed a cost-benefit test serves Congress's needs. ${ }^{128}$ Along with the legislative history, the "signing statement” interpreting the Act and the various bills introduced in the wake of the ergonomics veto also provides some strong clues as to the intended definition of "substantially the same."129 Secondly, the constraint that the text of any joint resolution of disapproval must be all-ornothing —all non-offending portions of the vetoed rule must fall along with the "bathwater"-

${ }^{127}$ See infra Parts IV.A.1, IV.A.4.

${ }^{128}$ But see Parks, supra note 123, at 199-205 (arguing that the CRA has been exercised not to increase accountability, but to appease special interest groups, leaving behind no clear statutory guidance for agencies). 
argues for a limited interpretation, as a far-reaching interpretation of "substantially the same” would limit an agency’s authority in ways Congress did not intend in exercising the veto. ${ }^{130}$ Third, in a system in which courts generally defer to an agency's own interpretation of its authority under an organic statute, agency action following a joint resolution of disapproval should also be given such deference. ${ }^{131}$ Finally, since a joint resolution of disapproval, read along with too broad an interpretation of "substantially the same," could significantly alter the scope of an agency’s authority under its organic statute, one should avoid that broad interpretation, since it seems implausible (or at least unwise), based on good government principles, that Congress would intend to significantly alter an agency’s delegated authority via the speedy and less-than-deliberative process it created to effect the CRA. ${ }^{132}$

\section{A. Congressional Intent and Language}

Whether the plain language of the CRA is viewed on its own or in the context of the events leading up to the passage of the statute and of the way in which Congress exercised its first and only disapproval action in 2001, it is clear that Congress intended the new streamlined regulatory veto process to serve two purposes, one pragmatic and one symbolic. It needed to create a chokepoint whereby Congress could focus its ire on "the worst of the worst"- those specific regulations that did the greatest offense to the general concept of "do more good than harm” or the ones that gored the oxen of specific interest groups with strong allies in Congress.

\footnotetext{
${ }^{129}$ See infra Parts IV.A.3, IV.A.5.

130 See infra Part IV.B.

${ }^{131}$ See infra Part IV.C.
} 
It also felt it needed, as the floor debate on the ergonomics standard made plain, to move the fulcrum on the scales governing the separation of powers so as to assert greater congressional control over the regulatory agencies whose budgets—but not always whose behavior-it authorizes. Neither of these purposes requires Congress to repudiate whole categories of agency activity when it rejects a single rule, as we will discuss in detail below. To use a mundane behavioral analogy, a parent who wants her child to bring home "the right kind of date” will clearly achieve that goal more efficiently, and with less backlash, by rejecting a specific suitor (perhaps with specific detail about how to avoid a repeat embarrassment) than by "grounding” the child or forbidding her from ever dating again. Even if Congress had wanted to be nefarious, with the only goal that of tying the offending agency in knots, it would better achieve that by vetoing a series of attempts to regulate, one after the other, then by barring the instant rule and all future rules in that area in one fell swoop.

But beginning with the plain language of the statute also shows that the regulatory veto was intended to preclude identical actions, not to preclude related actions informed by the lessons imparted through the first veto. Simply put, Congress put so much detail in the CRA about when and how an agency could try to reissue a vetoed rule that it seems bizarre for analysts to interpret "substantially the same" as a blanket prohibition against regulating in an area. We will explain how congressional intent sheds light on the precise meaning of "substantially the same," by examining five facets of the legislative arena: (1) the events leading up to the passage of the CRA; (2) the plain text of the statute; (3) the explanatory statement issued a few weeks after the CRA's passage by the three major leaders of the legislation in the Senate (and

\footnotetext{
${ }^{132}$ See infra Part IV.D.
} 
contemporaneously issued verbatim in the House); (4) the substantive (as opposed to the polemical) aspects of the ergonomics floor debate; and (5) the provisions of several bills subsequently proposed to restart the ergonomics regulatory process.

\section{Events Leading up to Passage}

One cannot interpret the CRA without looking at the political history behind it—both electoral and legislative. When the Republicans took over Congress after the 1994 elections, they intended to take action against regulations they felt were "wasteful" and that imposed significant burdens with few benefits. ${ }^{133}$ The CRA was drafted and adopted as a compromise in place of a moratorium on federal regulation ${ }^{134}$-it was intended to set up a process by which Congress could review individual regulations, often for their cost-benefit ratio. The political climate of the mid-1990s suggests that congressional Republicans sought to reform the administrative process in order to screen for rules whose benefits did not outweigh their costs. ${ }^{135}$ A Senate report on the moratorium proposal stated, "As taxpayers, the American people have a right to ask whether they are getting their money's worth. Currently, too few regulations are subjected to stringent cost/benefit analysis or risk assessment based on sound science. Without such protections, regulations can have unintended results.”"136 This led to the inclusion of, for example, a requirement that agencies submit the report of their rule not only to Congress, but

${ }^{133}$ See supra Part I.A (discussing the 1994 midterm elections and the Republicans’ promise of reforming federal regulation).

\footnotetext{
${ }^{134}$ See supra Part I.B.1 (describing the CRA’s procedural history).

135 See id.

${ }^{136}$ S. REP. NO. 104-15, at 5 (1995).
} 
also to GAO so that it can evaluate the CBA. ${ }^{137}$ Even if the proposed moratorium had gone into effect instead of the CRA, the bill would have allowed agencies to continue performing CBA, and the moratorium could even have ended early if Congress put stricter CBA requirements into place. ${ }^{138}$ Although there were some complaints about the "number" or "volume" of regulations as opposed to merely their efficiency ${ }^{139}$ _possibly suggesting that some members of Congress would not support even regulations whose benefits strongly outweighed their costs—-the overall political history of the CRA in the period from 1994 to 1996 sends a clear sign that CBA and risk assessment were key. A statute enacted in order to improve regulation should not be interpreted so as to foreclose regulation.

\section{Statutory Text}

The plain language of the CRA provides at least three hints to the intended meaning and import of the "substantially the same" provision (section 801(b)(2)). First, we note that in the second sentence of the statute, the first obligation of the agency issuing a rule (other than to submit a copy of the rule itself to the House and Senate) is to submit "a complete copy of the cost-benefit analysis of the rule, if any” to the Comptroller General and each house of Congress. ${ }^{140}$ Clearly, as we have discussed above, the CRA is a mechanism for Congress to scrutinize the costs and benefits of individual regulations, for possible veto of rules that appear to have costs in excess of benefits (a verdict that Congress either infers in the absence of an agency

137 See 5 U.S.C. § 801(a)(1)(B) (2006); 141 CONG. REC. S4700-01 (daily ed. Mar. 28, 1995) (statement of Sen. Domenici).

${ }^{138}$ H.R. 450, 104th Cong. (as passed by House of Representatives, Feb. 24, 1995).

139 See, e.g., S. REP. No. 104-15, at 5 ("Without significant new controls, the volume of regulations will only grow larger.”). 
statement on costs and benefits, makes using evidence contained in the agency CBA, or makes by rejecting conclusions to the contrary in the CBA). As we discuss in detail below, we believe the first place Congress therefore should and will look to see if the reissued rule is "in substantially the same form" as a vetoed rule is the CBA; a "similar-looking" rule that has a wholly different (and more favorable) balance between costs and benefit is simply not the same, as it will be different along precisely the key dimension about which Congress expressed paramount concern.

In addition, in the very sentence that bars an agency from reissuing a "substantially similar" rule, the Act provides for Congress to specifically authorize it to do just that, via a new law enacted after the veto resolution passes. ${ }^{141}$ We will discuss below, in the context of the April 1996 "signing statement," how Congress intended this provision to apply in the special case in which Congress had previously instructed the agency to issue almost precisely the rule it did issue, thereby leaving the agency caught between an affirmative requirement and a prohibition. So, other than needing such a mechanism to cover the rare cases where the agency is obligated to reissue a similar rule, why would Congress have specifically reserved the right to authorize a very similar rule to one it had recently taken the trouble to veto? We assert that there are only two logical explanations for this: (1) Congress might use the new specific authorization to clarify exactly what minor changes that might appear to leave the rule "substantially the same" would instead be sufficient to reverse all concerns that prompted the original veto; or

${ }^{140} 5$ U.S.C. $\S 801(a)(1)(B)(2006)$.

${ }^{141}$ See id. § 801(b)(2) (“[A] new rule that is substantially the same as [a vetoed] rule may not be issued, unless the reissued or new rule is specifically authorized by a law enacted after the date of the joint resolution disapproving of the original rule.” (emphasis added)). 
(2) Congress might come to realize that new information about costs and benefits, or changes in the underlying facts about the harm(s) addressed by the rules or about the costs of remedying them, made the original rule desirable going forward (or in hindsight). Because the passage of time can make the original veto look unwise (see interpretations 1 and 2 in the hierarchy in Part III.A), Congress needed a way to allow something "substantially similar" to pass muster despite the prohibition in the first part of section 801(b)(2). Whatever the precise circumstances of such a clarifying or about-face authorization, the very fact that Congress also anticipated occasional instances where similar or even identical rules could be reissued means logically that it clearly expected different rules to be reissued, making the interpretation of "substantially the same" as barring all further activity in a given problem area quite far-fetched.

Finally, section 803 of the CRA establishes a "special rule” for a regulation originally promulgated pursuant to a deadline set by Congress, the courts, or by another regulation. This section gives the agency whose rule is vetoed a one-year period to fulfill the original obligation to regulate. Such deadlines always specify at least the problem area the agency is obligated to address, ${ }^{142}$ so there is little or no question that Congress intended to allow agencies to reissue rules covering the same hazard(s) as a vetoed rule, in order to fulfill an obligation, so long as the revised rule approaches the problem(s) in ways not "substantially the same.” Further support for this common-sense interpretation of "substantially the same" is found in the time period established by section 803: one year to repropose and finalize a new rule is a breakneck pace in

${ }^{142}$ See, e.g., Needlestick Safety and Prevention Act, Pub. L. No. 106-430, § 5, 114 Stat. 1901 (2000) (establishing the procedure and deadline by which OSHA was required to promulgate amendments to its rule to decrease worker exposure to bloodborne pathogens). In this case, Congress went further and actually wrote the exact language it required OSHA to insert in amending the existing rule. 
light of the five to 10 years it not uncommonly takes agencies to regulate from start to finish, ${ }^{143}$ so in section 803 Congress chose a time frame compatible only with a very circumscribed set of "fixes" to respond to the original resolution of disapproval. If "not substantially the same" meant “unrecognizably different from,” one year would generally be quite insufficient to re-promulgate under these circumstances. Admittedly, Congress could have intended a different meaning for “substantially the same” in cases where no judicial, statutory, or regulatory deadline existed, but then one might well have expected section 803 to cross-reference section 802(b)(2) and make clear that a more liberal interpretation of "substantially the same” only applies to compliance with pre-existing deadlines.

\section{The "Signing Statement"}

In the absence of a formal legislative history, the explanatory statement written by the prime sponsors of the $\mathrm{CRA}^{144}$ serves its intended purpose as "guidance to the agencies, courts, and other interested parties when interpreting the act's terms." various elaborations that shed light on congressional expectations regarding agency latitude to reissue rules after disapproval.

The "background" section ${ }^{146}$ clarifies that Congress sought not to "become a super regulatory agency” speaking directly to the regulated community, but needed the CRA to tip the “delicate balance” between congressional enactment and executive branch implementation of

${ }^{143}$ See Stuart Shapiro, Two Months in the Life of the Regulatory State, ADMIN. \& REG. L. NEwS, Spring 2005, at 12, 15.

144 Cong. REC. S3683-87 (daily ed. Apr. 18, 1996) (joint statement of Sens. Nickles, Reid, and Stevens).

${ }^{145}$ Id. at $\mathrm{S} 3683$. 
laws, towards slightly more policymaking authority for Congress. Notably, the sponsors repeatedly referred to "a rule" in the singular noun form, rather than to whole regulatory programs, when they discussed the need for review (e.g., "Congress may find a rule to be too burdensome, excessive, inappropriate or duplicative”,147). In other words, agencies may take specific actions that usurp policymaking activity from Congress, so the remedy is for Congress to send them back to try again (to regulate consistent with their delegated authority), not to shut down the regulatory apparatus in an area. A CRA that had a "one strike, you're out” mechanism would, we believe, not "redress the delicate balance," but rewrite it entirely.

As discussed above, ${ }^{148}$ the passage of time or the advance of knowledge can ruin a wellintentioned rule and demand congressional intervention—Nickles, Reid, and Stevens refer to this by saying that "during the time lapse between passage of legislation and its implementation, the nature of the problem addressed, and its proper solution, can change." ${ }^{149}$ The principle that costs and benefits can be a moving target must, we believe, also inform the meaning of "substantially the same.” If the "proper solution” Congress envisioned to an environmental or other problem has changed such that an agency regulation no longer comports with congressional expectations, then it must also be possible for circumstances to change again such that a vetoed rule could turn out to effect "the proper solution.” The signing statement sets up a predicate for intervention

${ }^{146}$ Id. at S3683-84.

${ }^{147} I d$. at S3683 (emphasis added). In one instance only, the authors of this statement refer to "regulatory schemes" as perhaps being "at odds with Congressional expectations," perhaps in contrast to individual rules that conflict with those expectations. Id. at S3684. However, four sentences later in the same paragraph, they say that "if these concerns are sufficiently serious, Congress can stop the rule[,]" id. (emphasis added), suggesting that "schemes" does not connote an entire regulatory program or refer to all conceivable attempts to regulate to control a particular problem area, but simply refers to a single offending rule that is a "scheme."

${ }^{148}$ See supra Part III.A.

149142 Cong. REC. S3684 (daily ed. Apr. 18, 1996) (joint statement of Sens. Nickles, Reid, and Stevens). 
when the regulatory solution and the "proper solution” diverge-which in turn implies that an agency certainly cannot reissue "the same rule in the same fact situation,” but in rare cases it should be permitted to argue that what once was improper has now become proper. ${ }^{150}$ Whether in the 10 years since the ergonomics veto the 2000 rule still looks "improper" does not change the logic that costs and benefits can change by agency action or by exogenous factors, and that the purpose of the CRA is to block rules that fail a cost-benefit test.

The signing statement also offers up the "opportunity to act ... before the parties must invest the significant resources necessary to comply with a major rule" 151 as the sole reason for a law that delays the effectiveness of rules while Congress considers whether to veto them. Again, this perspective is consistent with the purpose of the CRA as a filter against agencies requiring costs in excess of their accompanying benefits, not as a means for Congress to reject all solutions to a particular problem by disapproving of one particular way to solve it.

The (brief) direct explanation of the "substantially the same” paragraph ${ }^{152}$ provides additional general impressions of likely congressional intent, as well as some specific elaboration of the remainder of section 801(b)(2). The only mention given to the purpose of the "substantially the same" prohibition is as follows: "subsection 801(b)(2) is necessary to prevent circumvention of a resolution disapproval [sic].” The use of the pejorative word “circumvention” seems clearly to signal congressional concern that an agency could fight and win a war of attrition simply by continuing to promulgate near-identical variants of a vetoed rule, until it finally caught Congress “asleep at the switch” or wary of having said "no” too many

\footnotetext{
150 See infra Part V.

151142 CoNG. REC. S3685 (daily ed. Apr. 18, 1996) (joint statement of Sens. Nickles, Reid, and Stevens).
} 
times. This rationale for invoking the "substantially the same” prohibition was echoed many times in the ergonomics floor debate, notably in this statement by Senator James Jeffords of Vermont: “an agency should not be able to reissue a disapproved rule merely by making minor changes, thereby claiming that the reissued regulation was a different entity."153 Viewed in this light, "substantially the same” means something akin to "different enough that it is clear the agency is not acting in bad faith.”

The remainder of the paragraph explaining section 801(b)(2) sheds more light on the process whereby Congress can even specifically authorize an agency to reissue a rule that is not "substantially different.” Here the sponsors made clear that if the underlying statute under which the agency issued the vetoed rule doesn't constrain the substance of such a rule, "the agency may exercise its broad discretion to issue a substantially different rule."154 Notice that the sponsors make no mention of the agency needing any permission from Congress to do so. However, in some cases Congress has obliged an agency to issue a rule and has imposed specific requirements governing what such a rule should and should not contain. ${ }^{155}$ When Congress disapproves of this sort of rule, "the enactment of a resolution disapproval for that rule may work to prohibit the reissuance of any rule.” ${ }^{\prime 156}$ In these cases, the sponsors clarify, the "debate on any resolution of disapproval [should] make the Congressional intent clear regarding the agency’s options or lack thereof.”157 If an agency is allowed by the original statute to issue a substantially

\footnotetext{
152 See id. at S3686.

153147 Cong. REC. S1832 (daily ed. Mar. 6, 2001) (statement of Sen. Jeffords).

154142 Cong. REC. S3686 (daily ed. Apr. 18, 1996) (joint statement of Sens. Nickles, Reid, and Stevens).

155 See, e.g., supra note 142.

156142 Cong. REC. S3686 (daily ed. Apr. 18, 1996) (joint statement of Sens. Nickles, Reid, and Stevens). ${ }^{157}$ Id.
} 
different rule, Congress has no obligation to speak further, but if the veto and the statute collide, then Congress must explain the seeming paradox. Such a case has never occurred, of course (the OSH Act does not require OSHA to issue any kind of ergonomics rule), but we can offer informed speculation about the likely contours of such an event. Suppose that in 2015, Congress was to pass a law requiring the Department of Transportation (DOT) to issue a regulation by January 1, 2018, prohibiting drivers from writing text messages while driving. But by 2018, suppose the makeup of Congress had changed, as had the party in control of the White House, and the new Congress was not pleased that DOT had followed the old Congress's instructions to the letter. It could veto the rule and make clear that DOT had no options left—perhaps it could save face in light of this flip-flop by claiming that new technology had made it possible to text safely, and Congress could simply assert that the original order to regulate was now moot. Or, Congress could observe (or claim) that DOT had followed the original instructions in a particularly clumsy way: perhaps it had brushed aside pleas from certain constituency groups (physicians, perhaps) who asserted that more harm to public safety would ensue if they were not exempted from the regulations. Congress could resolve this paradox by instructing DOT to reissue the rule with one additional sentence carving out such an exemption. That new document would probably be "substantially the same" as the vetoed rule, and might have costs and benefits virtually unchanged from those of the previous rule, but it would be permissible because Congress had in effect amended its original instructions from 2015 to express its will more clearly.

Because Congress specifically provided the agency with an escape valve (a written authorization on how to proceed) in the event of a head-on conflict between a statutory obligation and a congressional veto, it is clear that no such authorization is needed if the agency 
can craft on its own a "substantially different" rule that still comports with the original statute. Although various members did introduce bills in the several years after the ergonomics veto that (had they passed) would have required OSHA to promulgate a new ergonomics rule, ${ }^{158}$ we believe it is clear that a new law requiring an agency to act (especially when an agency appears more than content with the prior veto) is not necessary to allow that agency to act, as long as it could produce a revision sufficiently different from the original so as not to "circumvent" the veto. The special process designed to avoid situations when the veto might preclude all regulation in a particular area simply suggests that Congress intended that none of its vetoes should ever have such broad repercussions.

\section{Ergonomics Floor Debate-Substantive Clues}

Although we argued above that many of the general statements about the CRA itself during the ergonomics debate should be dismissed as political posturing, during that debate there were also statements for or against the specific resolution of disapproval that provide clues to the intended meaning of "substantially similar." Statements about the actual rule being debated, rather than the hypothetical future effect of striking it down, can presumably be interpreted at face value - in particular, opponents of the rule would have a disincentive to play down their substantive concerns, lest swing voters decide that the rule was not so bad after all. And yet, while several of the key opponents emphasized very specific concerns with the rule at hand, they stated their objections in heated terms and yet clearly left open the door for OSHA to take specific steps to improve the rule. For example, Republican Representative John Sweeney of New York made plain: "My vote of no confidence on the ergonomics regulations does not mean

${ }^{158}$ See infra Part IV.A.5. 
I oppose an ergonomics standard; I just oppose this one”-primarily in his view because it did not specify impermissible levels of repetitive stress along the key dimensions of workplace ergonomics (force, weight, posture, vibration, etc.) that would give employers confidence they knew what constituted compliance with the regulation. Similarly, Republican Representative Charles Norwood of Georgia emphasized that the vagueness of the OSHA rule "will hurt the workers," and said that "when we have [a rule] that is bad and wrong, . . . then we should do away with it and begin again.”

Interpretations of "substantially similar" that assume the agency is barred from reregulating in the same subject area therefore seem to ignore how focused the ergonomics debate was on the consternation in Congress with the specific provisions of the OSHA final rule. Although opponents might have felt wary of stating emphatically that they opposed any attempt to control ergonomic hazards, it nevertheless was the case that even the staunchest opponents focused on the "wrong ways to solve the ergonomics problem" rather than on the inappropriateness of any rule in this area.

\section{Subsequent Activity}

Legislative activity following the veto of the ergonomics rule may suggest that at least some in Congress thought that OSHA may require specific authorization to propose a new ergonomics rule. In particular, in 2002 Senator John Breaux of Louisiana introduced S. 2184, which included a specific authorization pursuant to the CRA for OSHA to issue a new 
ergonomic rule. ${ }^{159}$ The presence of a specific authorization in S. 2184 may imply that the bill's sponsors believed that such an authorization was necessary in order for OSHA to promulgate a new ergonomics regulation.

Other circumstances, however, suggest more strongly that the inclusion of this specific authorization may have been merely a safeguard rather than the purpose of the bill. The bill's mandate that OSHA issue a new rule within two years of the enactment of S. $2184^{160}$ clearly indicates that the sponsors intended to spur a recalcitrant agency to take some action under the Republican administration. The bill's findings do not state that OSHA had been otherwise prohibited from issuing a new ergonomics rule-indeed, the findings do not mention Congress's 2001 veto at all. ${ }^{161}$ Thus, the congressional authorization may have instead served to preempt a Bush administration belief (or pretext) that Congress's earlier veto prohibited OSHA from further regulating workplace ergonomics. ${ }^{162}$

${ }^{159}$ See S. 2184, 107th Cong. § 1(b)(4) (as introduced in Senate, Apr. 17, 2002) (“Paragraph (1) [which requires OSHA to issue a new ergonomics rule] shall be considered a specific authorization by Congress in accordance with Section 801(b)(2) of Title 5, United States Code.”). S. 2184 never made it into law.

${ }^{160} I d$. § 1(b)(1) ("Notwithstanding any other provision of law, not later than 2 years after the date of enactment of this Act, the Secretary of Labor shall, in accordance with section 6 of the [OSH Act], issue a final rule relating to ergonomics.").

${ }^{161}$ See id. § 1(a).

${ }^{162}$ Cf. Departments of Labor, Health and Human Services, and Education, and Related Agencies Appropriations for Fiscal Year 2002: Hearing on H.R. 3061/S.1536 Before a Subcomm. of the S. Comm. on Appropriations, 107th Cong. 72 (2001) (statement of Elaine L. Chao, Secretary, United States Department of Labor) (hesitating to "expend valuable—and limited—resources on a new effort" to regulate workplace ergonomics following Congress's 2001 veto). 


\section{B. All or Nothing}

Another tool for interpreting the substantial similarity provision lies in the CRA's choice to provide only a "nuclear option" to deal with a troublesome rule. The CRA provides a nonamendable template for any joint resolution of disapproval, which allows only for repealing an entire rule, not just specific provisions. ${ }^{163}$ Furthermore, there is "no language anywhere [in the CRA that] expressly refers in any manner to a part of any rule under review." ${ }^{164}$ An inability to sever certain provisions while upholding others is consistent with the CRA's contemplation of a “speedy, definitive and limited process" because "piecemeal consideration would delay and perhaps obstruct legislative resolution ....,"165

Because an offending portion of the rule is not severable, Congress has decided to weigh only whether on balance, the bad aspects of the rule outweigh the good. For example, even when they argued against certain provisions of the OSHA ergonomics regulation, congressional Republicans still noted that they supported some type of ergonomics rule. ${ }^{166}$ Since the CRA strikes down an entire rule even though Congress may support certain portions of that rule, it only makes sense to read the substantial similarity provision as allowing the non-offending provisions to be incorporated into a future rule. If an agency were not allowed to even reissue the parts of a rule that Congress does support, that would lead to what some have called a

\footnotetext{
163 See 5 U.S.C. § 802 (2006) (requiring that a joint resolution of disapproval read: “That Congress disapproves the rule submitted by the relating to , and such rule shall have no force or effect”).

${ }^{164}$ Rosenberg, supra note 64, at 1065.

${ }^{165}$ Id. at 1066.

${ }^{166}$ See, e.g., 147 CONG. REC. S1859 (daily ed. Mar. 6, 2001) (statement of Sen. Nickles) (expressing support for a "more cost effective" ergonomics rule).
} 
“draconian result."167 To the extent that interpreting the CRA prevents agencies from issuing congressional-approved portions of a rule, such an interpretation should be avoided.

Congress did not choose a mechanism that would have allowed for "line item vetoes" of parts of rules. Instead, the simple — yet broad and unchangeable—joint resolution language that a veto means merely that the rule has not survived a "speedy and limited" review. To give effect to the intent of Congress in issuing its veto, it only makes sense to allow provisions to pass through in future regulations that were never objectionable to Congress in the first place.

\section{Deference to Agency Expertise}

Since courts are generally deferential to an agency’s interpretation of its delegated authority, ${ }^{168}$ a joint resolution of disapproval should not be interpreted to apply too broadly if an agency wishes to promulgate one or more rules addressing the same issues as the repealed rule. There are, however, two important limitations to this general principle of deference that may apply to agency actions taking place after a Congress overturns a rule: First, where Congress overturns a rule because it believes the agency acted outside the scope of its delegated authority under the organic statute, a court might choose to weigh this congressional intent as a factor against deference to the agency, if the reissued rule offends against this principle in a similar way. Second, where Congress overturns a rule because it finds that the agency was "lawmaking," this raises another statutory—if not constitutional—reason why agency deference

\footnotetext{
${ }^{167}$ Rosenberg, supra note 64, at 1066.

${ }^{168}$ See infra Part IV.C.1.
} 
might not be applied. This Section presents the issue of deference generally, and then lays forth the two exceptions to this general rule.

\section{Chevron Deference}

In Chevron U.S.A., Inc. v. Natural Resources Defense Council, the Supreme Court held that, unless the organic statute is itself clear, a court should defer to an agency's reasonable interpretation of its own delegated authority. ${ }^{169}$ The Court's decision was based on the notion of agency expertise: since agencies are more familiar with the subject matter over which they regulate, they are better-equipped to understand their grant of rulemaking authority. ${ }^{170}$ Where Congress delegates rulemaking authority to an administrative agency, it is inevitable that the delegation will include some ambiguities or "gaps."171 In order for an agency to effectively carry out its delegated authority, there must be a policy in place that fills the gaps left by Congress. In Chevron, the Court reasoned that gaps were delegations, either express or implicit, granting the agency the authority "to elucidate a specific provision of the statute by regulation."172 The Court has recognized that "[t]he responsibilities for assessing the wisdom of such policy choices and resolving the struggle between competing views of the public interest are not judicial ones ....”173 The Chevron Court thus created a two-part test that respects agency expertise by deferring to reasonable interpretations of ambiguity in a delegation of authority: First, a court

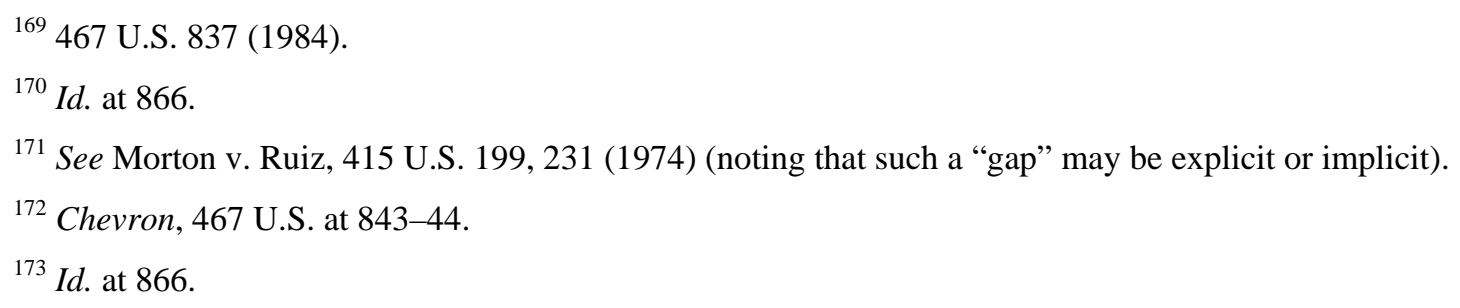


must determine "whether Congress has directly spoken to the precise question at issue." 174 If so, both the court and the agency "must give effect to the unambiguously expressed intent of Congress.”175 If Congress has not spoken to the issue directly, however, the second step of Chevron requires a court to defer to the agency's construction of the statute if it is a "permissible" interpretation, whether or not the court agrees that the interpretation is the correct one. $^{176}$

Because a resolution repealing a rule under the CRA limits an agency’s delegated authority by prohibiting it from promulgating a rule that is substantially similar, the Chevron doctrine should apply here. The CRA proscription against an agency reissuing a vetoed rule "in substantially the same form” is an ambiguous limitation to an agency’s delegated authority. That standard must understandably be a hazy limitation as it applies to all agencies whose rules are reviewable by Congress. However, the other relevant statutory text, the joint resolution of disapproval itself, does not resolve the ambiguity. It cannot provide any evidence that Congress has "directly spoken to the precise question at issue"177_namely, what form of regulation would constitute a substantially similar reissuance of the rejected rule--because the text can only effect a repeal of the rule, and no more. ${ }^{178}$ Although a court, in the absence of clear, enacted statutory language, might look to legislative history to determine whether Congress has “spoken to” the

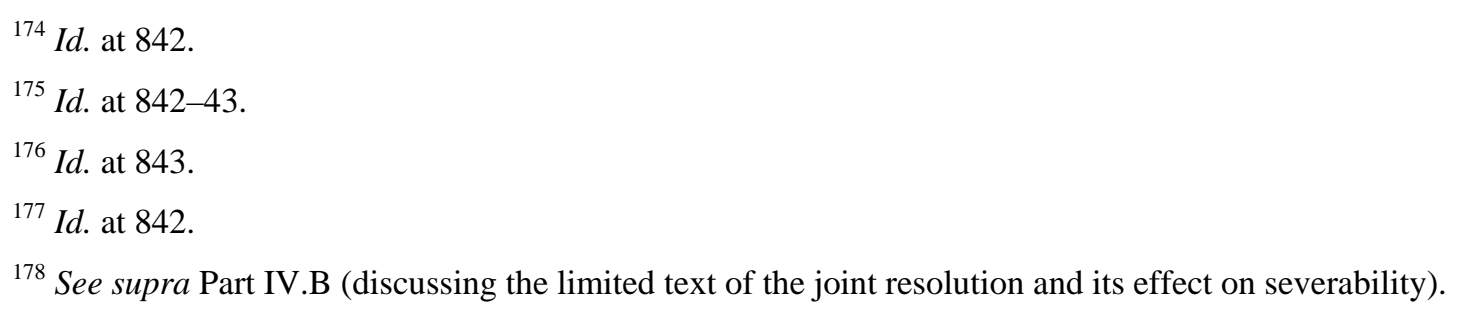
The notion of congressional intent, however, may be relevant to the scope of an agency's authority following action under the CRA, at least where the subject matter is politically and economically significant, and where there is a broader legislative scheme in place. See infra Part IV.C.2 (discussing the effect of FDA v. Brown \& Williamson Tobacco Corp., 529 U.S. 120 (2000), on application of the Chevron doctrine). 
issue, too many disparate (and perhaps disingenuous) arguments on the floor make this unworkable as a judicial doctrine without any textual hook to hang it on. ${ }^{179}$

Chevron step one, then, cannot end the inquiry; we must proceed to step two. The agency's interpretation, if permissible, should then receive deference. While some minor transposition of a rejected rule's language effecting no substantive change could certainly be deemed impermissible under the CRA, changes that are significant enough to affect the costbenefit ratio are similar to the "policy choices" that the Court has held are not within the responsibility of the judiciary to balance. ${ }^{180}$ Thus, comparing side-by-side the language of a vetoed rule and the subsequently promulgated rule is inadequate without considering the substantive changes effected by any difference in language, however minor. Under the reasoning in Chevron, a court should give substantial deference to an agency in determining whether, for purposes of the CRA, a rule is substantially different from the vetoed rule.

\section{Ultra Vires Limitation}

Admittedly, there are important considerations that may counsel against applying Chevron deference in particular situations. One such situation might occur if Congress's original veto were built upon a finding that the agency misunderstood its own power under the organic statute. In that case, a court might choose to consider Congress's findings as a limitation on the applicability of Chevron deference. This consideration provided the background for the

\footnotetext{
${ }^{179}$ See, e.g., Zedner v. United States, 547 U.S. 489, 509-11 (2006) (Scalia, J., concurring) (filing a separate opinion for the specific purpose of admonishing the majority's citation to legislative history, noting that use of legislative history in statutory interpretation "accustoms us to believing that what is said by a single person in a floor debate or by a committee report represents the view of Congress as a whole").

${ }^{180}$ Chevron, 467 U.S. at 866.
} 
Supreme Court's decision in FDA v. Brown \& Williamson Tobacco Corp., in which the Court struck down regulation of tobacco products by the Food and Drug Administration (FDA). ${ }^{181}$ The Court looked to congressional intent in determining the boundaries of FDA's authority under the Food, Drug and Cosmetic Act (FDCA), finding that the statute's use of the words "drug” and “device” clearly did not grant FDA the power to regulate tobacco products, and the regulation thus failed the first prong of the Chevron test. ${ }^{182}$ The FDCA “clearly" spoke to the issue, and therefore FDA's interpretation of its power was not entitled to deference. Importantly, the Court found this clarity not within the text of the FDCA itself, but in other legislative actions since the FDCA's enactment. In writing for the majority, Justice O’Connor pointed out that, in the decades following the FDCA's enactment, Congress passed various pieces of legislation restricting — but not entirely prohibiting — certain behavior of the tobacco industry, indicating a congressional presumption that sale of tobacco products would still be permitted. ${ }^{183}$ The Court found that this presumption clearly contradicted FDA's interpretation that "drug” and "device” in the FDCA included tobacco products because, if FDA's interpretation were correct, the agency would be required to ban the sale of tobacco products because "safety" is a prerequisite for sale of a drug or device under the FDCA, and no tobacco product is "safe."184 The four dissenting Justices criticized the majority’s reliance on inferred Congressional intent, arguing that the

181529 U.S. 120 (2000).

${ }^{182}$ Id. at 160-61 ("It is . . . clear, based on the FDCA's overall regulatory scheme and the subsequent tobacco legislation, that Congress has directly spoken to the question at issue and precluded the FDA from regulating tobacco products.”).

${ }^{183}$ Id. at $137-39$.

${ }^{184}$ Id. at 133-35 ("These findings logically imply that, if tobacco products were 'devices' under the FDCA, the FDA would be required to remove them from the market."). 
Chevron approach to statutory interpretation should principally focus on the text of the organic statute. $^{185}$

If Congress, in enacting a joint resolution pursuant to the CRA, were to make clear that it thought an agency's regulation was outside the scope of its statutory grant of authority, a court might consider this a factor limiting its deference to the agency. In other words, the CRA veto might be considered a "clarification" of the organic statute in a way similar to the tobaccorelated legislative activity considered by the Court in FDA v. Brown \& Williamson. ${ }^{186}$ There are seeds of this issue in the congressional debates over the ergonomics rule, where Republicans argued that part of the rule countervened a provision in the OSH Act because, under their interpretation, the regulation superseded state worker’s compensation laws. ${ }^{187}$ In a less controversial situation, however, Brown \& Williamson might require (or at least encourage) a court to consider the congressional rationale for overturning a rule as a factor in evaluating the validity of a new rule issued in the same area. Like the decision in Brown \& Williamson, however, the factor might only be compelling if there were also a broader legislative scheme in place.

\footnotetext{
${ }^{185}$ Id. at 167-81 (Breyer, J., dissenting) (arguing for a "literal” interpretation of the FDCA).

${ }^{186}$ See supra note 183 and accompanying text.

${ }^{187}$ See OSH Act § 4(b)(4), 29 U.S.C. § 653(b)(4) (2006) ("Nothing in this Act shall be construed to supersede or in any manner affect any workmen's compensation law . ...”); 147 CONG. REC. S1832 (daily ed. Mar. 6, 2001) (statement of Sen. Jeffords) ("[OSHA] ignored, in issuing its ergo standard, the clear statutory mandate in section 4 of the OSH Act not to regulate in the area of workmen's compensation law."). Senator Nickles argued that, even if it were within OSHA's delegated power, the regulation would supersede "more generous" state worker's compensation law. 147 CONG. REC. S1833 (daily ed. Mar. 6, 2001) (statement of Sen. Nickles). We argue below that this interpretation may have been incorrect on its face. See infra Part VI.B.
} 


\section{3. “Lawmaking” Limitation}

Another limiting principle on agency discretion is found where the agency action blurs the lines of regulation and steps into the field of "lawmaking." Where such an action takes place, the non-delegation doctrine is implicated and presents questions of either constitutionality or agency adherence to its limited grant of authority. Separation of powers considerations provide the background for this principle.

In the debates over the ergonomics rule, opponents of the regulation contended that OSHA was writing the "law of the land" and that the elected members of Congress, not bureaucrats, are supposed to exercise that sort of authority. ${ }^{188}$ Senator Nickles made clear that he saw the ergonomics rule as a usurpation of Congress's legislative power. He referred to the rule as "legislation” and argued, “[W]e are the legislative body. If we want to legislate in this area, introduce a bill and we will consider it.”189 This argument that an administrative agency has exercised legislative power has constitutional implications. Article I of the Constitution provides that the Senate and House of Representatives have the sole legislative power. ${ }^{190}$ In the administrative state, this constitutional provision has given rise to the non-delegation doctrine, by which Congress may not delegate its lawmaking authority to an executive agency. ${ }^{191}$ In order to

188147 CoNG. REC. S1833 (daily ed. Mar. 6, 2001) (statement of Sen. Nickles).

${ }^{189} I d$.

${ }^{190}$ U.S. CONST. art. I, § 1 (“All legislative Powers herein granted shall be vested in a Congress of the United States, which shall consist of a Senate and House of Representatives.”).

${ }^{191}$ See, e.g., A.L.A. Schechter Poultry Corp. v. United States, 295 U.S. 495 (1935) (holding that the National Industrial Recovery Act's authorization to the President to prescribe "codes of fair competition" was an unconstitutional delegation of legislative power because the statutory standard was insufficient to curb the discretion of the executive branch). 
meet constitutional requirements under this doctrine, the organic statute needs to provide the agency with an “intelligible principle to which [the agency] is directed to conform . . .."192

Violations of the non-delegation doctrine, however, are rarely found. Instead, the courts employ a canon of constitutional avoidance in order to circumvent delegation issues. Under this canon of interpretation, a court confronted with a statute that appears to delegate lawmaking power to an agency will search for a narrower, constitutionally permissible interpretation of the statute. If such an interpretation is available, the court will not invalidate the statute, but will instead strike down the agency action as exceeding the (narrower, constitutionally permissible) grant of authority. ${ }^{193}$ The Benzene Case is one example in which the Supreme Court has employed this canon in order to avoid striking down a delegation of authority to an administrative agency. ${ }^{194}$ In that case, the Court considered an OSHA rule which limited permissible workplace exposure levels to the chemical benzene to one part per million. That standard was set pursuant to the statutory delegation of authority instructing OSHA to implement standards “reasonably necessary or appropriate to provide safe or healthful employment . . ..”195 Rather than consider that the "reasonably necessary or appropriate” standard was unintelligible and unconstitutionally broad, the Court instead held that OSHA exceeded its rulemaking authority because the agency did not make the necessary scientific findings and based its exposure rule on impermissible qualitative assumptions about the correlation between cancer

192 J.W. Hampton, Jr., \& Co. v. United States, 276 U.S. 394, 409 (1928).

193 See generally Matthew D. Adler, Judicial Restraint in the Administrative State: Beyond the Countermajoritarian Difficulty, 145 U. PA. L. REV. 759, 835-39 (1997) (describing the canon of constitutional avoidance and arguing that "the criteria bearing on constitutionality figure in the best interpretation of statutes, at least where statutes are otherwise taken to be indeterminate”).

194 Indus. Union Dep’t v. Am. Petroleum Inst. (Benzene Case), 448 U.S. 607 (1980).

${ }^{195} \mathrm{Id}$. at 613. 
risks and small doses of benzene, rather than on a quantitative assessment that found a

“significant risk” predicate for regulating to $1 \mathrm{ppm} .{ }^{196}$

If Congress vetoes an agency regulation on the ground that it is "lawmaking," this may be taken to mean one of two things: either Congress believes that the agency was acting outside of its delegated authority, or it believes that the organic statute unconstitutionally grants the agency legislative power. Since, reflecting the avoidance canon, unconstitutional delegations have only been found twice ${ }^{197}$ in the history of our administrative state, and since repealing a single rule would be insufficient to correct that type of constitutional defect in the organic statute, it seems clear that by "lawmaking” Congress must mean that the agency exceeded its statutory authority. ${ }^{198}$ In other words, if Congress actually did mean that the organic statute is impermissibly broad, the legislature's responsibilities lie far beyond vetoing the single rule, and would seemingly require curing the constitutional defect by amending the organic statute. But because the veto unlikely signals such a sweeping change and admission of a law's unconstitutionality, this brings us back to the Brown \& Williamson issue, discussed above, where an agency still deserves deference in promulgating subsequent rules, although congressional intent may limit that deference if there is a legislative scheme in place. ${ }^{199}$

${ }^{196}$ Id. at 662.

${ }^{197}$ The two cases are A.L.A. Schechter Poultry Corp. v. United States, 295 U.S. 495 (1935), and Panama Refining Co. v. Ryan, 295 U.S. 338 (1935). For a discussion on the constitutionality of OSHA's organic statute, see generally Cass R. Sunstein, Is OSHA Unconstitutional?, 94 VA. L. REV. 1407 (2008).

${ }^{198}$ In this respect, it is worth noting that the Republicans' "lawmaking” objections during the ergonomics rule debate were rather non-specific. The legislators did not point to any "unintelligible" principle under which the rule was promulgated, or define what characteristics of the ergonomics rule brought it out of the normal "rulemaking" category and into the realm of "lawmaking," besides voicing their displeasure with some of its substance. Indeed, the "lawmaking" argument was apparently conflated with the notion that OSHA had acted outside of its authority, properly delegated. See supra note 187 and accompanying text.

\footnotetext{
${ }^{199}$ See supra Part IV.C.2.
} 
On the other hand, it is possible-even likely_-that Senator Nickles and his colleagues were merely speaking colloquially in accusing OSHA of "lawmaking," and meant that the agency was legislating in a softer, non-constitutional sense. If their objection meant that they found the regulation a statutorily_-but not constitutionally-excessive exercise, then they are in essence making the ultra vires objection discussed above. ${ }^{200}$ If, on the other hand, their objection meant that OSHA did have both the statutory and constitutional authority to promulgate the regulation, but that the agency was simply flexing more power than it should simply as a matter of policy, then a veto on those grounds would in essence be an attempt to retract some of the authority that Congress had delegated to the agency. As discussed below, Congress should be hesitant to use the CRA to substantively change an intelligible principle provided in the organic statute, and a court should hesitate to interpret the CRA to allow for such a sweeping changethe CRA process is an expedited mechanism that decreases deliberativeness by imposing strict limitations on time and procedure. ${ }^{201}$

In any case, the "lawmaking” objection during a congressional veto essentially folds back up into one of the problems discussed previously-either it presents an issue of the agency exceeding its statutory authority and possibly affecting the deference due subsequent agency actions, or, failing that, it means that some members of Congress are attempting grab back via an expedited process some authority properly delegated to the agency.

\footnotetext{
${ }^{200}$ See id.

${ }^{201}$ See infra Part IV.D.1.
} 
The issue of deference to an agency ought not differ too much between the CRA and the traditional (pre-1996) context. Both of these contexts involve an agency's judgment about what policies it can make under its authorizing legislation, since the "substantial similarity" provision is an after-the-fact limitation on the agency’s statutorily-authorized rulemaking power. Neither the CRA nor its joint resolution template provide enough guidance to end the inquiry at Chevron step one. A court, then, should employ a narrow interpretation of the CRA's substantial similarity provision, giving substantial deference to an agency’s determination that the new version of a rejected rule is not "substantially similar" to its vetoed predecessor. This interpretation would, however, be limited by the "permissibility” requirement of Chevron step two, as well as considerations of delegation and of congressional findings that an agency has misunderstood its statute.

\section{Good Government Principles}

Various members of Congress argued during the ergonomics floor debate that OSHA and other regulatory agencies should be chastened when they stray from their mission (regulation) into congressional territory (legislation). Arguably, Congress itself should also eschew “legislation by regulation,” even though Congress clearly has the legislative authority. In this Section, we argue that Congress should not use a veto of an isolated piece of rulemaking to effect statutory change - it should do so through a direct and deliberative process that the CRA does not offer. In addition, we offer another "good government” rationale for interpreting “substantially the same” in a narrow way. 


\section{Reluctance to Amend Congress's Delegation to the Agency}

One should be hesitant to interpret the substantial similarity provision too broadly because doing so could allow expedited joint resolutions to serve as de facto amendments to the original delegation of authority under the relevant organic statute. If the bar against reissuing a rule "in substantially the same form” applied to a wide swath of rules that could be promulgated within the agency's delegated rulemaking authority, this would be tantamount to substantively amending the organic statute.

The OSHA ergonomics regulation illustrates this point nicely. Section 6 of the OSH Act grants OSHA broad authority to promulgate regulations setting workplace safety and health standards. ${ }^{202}$ With the exception of one aspect of the ergonomics rule, ${ }^{203}$ congressional Republicans admitted that OSHA's broad authority did in fact include the power to promulgate the regulation as issued. ${ }^{204}$ If it is within OSHA's delegated authority to promulgate rules setting ergonomics standards, and enactment of the joint resolution would prevent OSHA from promulgating any ergonomics standards in the future, then the joint resolution would constitute a significant amendment to the organic statute. Indeed, one of the two parts of OSHA's mission as put in place by the OSH Act-the responsibility to promulgate and enforce standards that lessen the risk of chronic occupational disease (as opposed to instantaneous occupational accidents)— really involves four basic types of risk factors: chemical, biological, radiological, and ergonomic

202 See OSH Act § 6, 29 U.S.C. § 655 (2006); see also 147 CONG. REC. S1832 (daily ed. Mar. 6, 2001) (statement of Sen. Jeffords) ("OSHA, of course, has enormously broad regulatory authority. Section 6 of the OSH Act is a grant of broad authority to issue workplace safety and health standards.”).

203 See supra note 187 and accompanying text.

${ }^{204}$ See 147 CONG. REC. S1838 (daily ed. Mar. 6, 2001) (statement of Sen. Enzi) ("The power for OSHA to write this rule did not materialize out of thin air. We in Congress did give that authority to OSHA ....”). 
hazards. In this case, "vetoing the topic" when vetoing one rule in that rubric would amount to taking a significant subset of the entire agency mission away from the executive branch, without actually opening up the statute to any scrutiny.

We see two major reasons why courts should not interpret the CRA in such a way that effectively amends an organic statute via an expedited joint resolution. First, there is a rule of statutory interpretation whereby, absent clear intent by Congress to overturn a prior law, legislation should not be read to conflict with the prior law. ${ }^{205}$ Second, it seems especially doubtful that Congress would intend to allow modification of an organic statute via an expedited legislative process. ${ }^{206}$ Significant changes—-such as major changes to a federal agency’s statutory grant of rulemaking authority—generally take more deliberation and debate. The CRA process, on the other hand, creates both a ten-hour limit for floor debates and a shortened time frame in which Congress may consider the rule after the agency reports it. ${ }^{207}$ For these reasons, it would be implausible to read the substantial similarity provision as barring reissuance of a rule simply because it dealt with the same subject as a repealed rule.

${ }^{205}$ See, e.g., Finley v. United States, 490 U.S. 545, 554 (2003) (“[N]o changes in law or policy are to be presumed from changes of language in [a] revision unless an intent to make such changes is clearly expressed.” (internal quotation omitted)), superceded by statute, 28 U.S.C. § 1367 (2006); Williams v. Taylor, 529 U.S. 362, 379 (2000) (plurality opinion) (arguing that, if Congress intended the Antiterrorism and Effective Death Penalty Act to overturn prior rules regarding deference to state courts on questions of federal law in habeas proceedings, then Congress would have expressed that intent more clearly); cf. United States v. Republic Steel Corp., 264 F.2d 289, 299 (7th Cir. 1959) (stating that "there should not be attributed to Congress an intent to produce such a drastic change, in the absence of clear and compelling statutory language”), rev'd on other grounds, 362 U.S. 482 (1960).

${ }^{206}$ See also Rosenberg, supra note 64, at 1066 (noting that the CRA “contemplates a speedy, definitive and limited process").

${ }^{207}$ See supra Part I.B.3 (describing the CRA procedure). 


\section{Other "Good Government” Rationales}

Allowing an agency to reissue a vetoed rule with a significantly more favorable costbenefit balance is a victory for congressional oversight, not a “circumvention” of it. “Substantially the same” is unavoidably a subjective judgment, so we urge that such judgments give the benefit of the doubt to the agency—not so that a prior veto would immunize the agency against bad conduct, but so that the second rule would allow the agency (through its allies in Congress, if any) to defend the rule a second time on its merits, rather than having it summarily dismissed as a "circumvention.” A “meta-cost-benefit" analysis of the decision to allow a rule of doubtful dissimilarity back into the CRA veto process would look something like this: the cost of allowing debate on a rule that the majority comes to agree is either a circumvention of section 801(b)(2), or needs to be struck down a second time on the merits, can be measured in personhours - roughly 10 hours or less of debate in each house. The benefits of allowing such a debate to proceed can be measured in the positive net benefit accruing to society from allowing the rule to take effect (assuming that Congress will act to veto a rule with negative net benefit). ${ }^{208}$ The benefits of the additional discussion will not always outweigh the costs thereof, but we suggest that whenever "substantially the same" is a controversial or close call, the opportunity for another brief discussion of the rule’s merits is a safer call to make than a "silent veto" invoking section $801(b)(2)$.

${ }^{208}$ As for the number of such possibly cost-ineffective debates, we simply observe that if OSHA were to repropose an ergonomics rule, and Congress were to allow brief debate on it despite possible arguments that any ergonomics rule would be a circumvention of section 801(b)(2), this would be the first such "wasteful" debate in a minimum of ten years. 


\section{What Does “Substantially the SAme” Really Mean?}

In light of the foregoing analysis, we contend that only among the first four interpretations in Part III.A above could the correct meaning of "substantially the same” possibly be found. Again, to comport literally with the proper instructions of section 801(b)(2) does not insulate the agency against a subsequent veto on substantive grounds, but it should force Congress to debate the reissued rule on its merits, rather than the "faster fast-track" of simply declaring it to be an invalid circumvention of the original resolution of disapproval. To hone in more closely on exactly what we think "substantially the same” requires, we will examine each of the four more "permissive” interpretations in Part III.A, in reverse order of their presentation—and we will argue that any of the four (except for Interpretation 1) might be correct in particular future circumstances.

Interpretation 4 (the agency must change the cost-benefit balance and must fix any problems Congress identified when it vetoed the rule) has some appeal, but only if Congress either would amend the CRA to require a vote on a "bill of particulars" listing the specific

reasons for the veto, or at least did so sua sponte in a particular future case. ${ }^{209}$ Arguably, the agency should not have unfettered discretion to change the costs and benefits of a rule as it sees fit, if Congress had already objected to specific provisions that contributed to the overall failure of a benefit-cost test. A new ergonomics rule that had far lower costs and/or far greater benefits, but that persisted in establishing a payout system that made specific reference to state workers’ compensation levels, might come across as "substantially the same" in a way Congress could

${ }^{209}$ See infra Part VII. 
object to as OSHA being oblivious to the previous veto. ${ }^{210}$ However, absent a clear statement of particulars from Congress, the agencies should not be forced to read Congress's mind. A member who strenuously objected to a particular provision should be free to urge a second veto if the reissued rule contains an unchanged version of that provision, but if she cannot convince a majority in each house to call for that specific provision's removal, Congress (or a court) should not dismiss as "substantially the same" a rule containing a provision that might have been (and might still be) supported by most or nearly all members.

Interpretation 3 (the agency's task is to significantly improve the cost-benefit balance, nothing more) makes the most sense in light of our analysis, and should become the commonlyunderstood default position. The CRA is essentially the ad hoc version of the failed DoleJohnston regulatory reform bill—rather than requiring agencies to produce cost-beneficial rules (and prescribing how Congress thought they should do so), the CRA simply reserves to Congress the right to reject on a case-by-case basis any rule whose stated costs exceed stated benefits, or (if the votes are there) one for which third-party assertions about costs exceed stated or asserted benefits. The way to reissue something "distinctly different" is to craft a rule whose benefit-cost balance is much more favorable. Again, this could be effected with one word change in a massive document, if that word (for example) halves the stringency and/or halves the cost compared to the original. Or, a rule missing one word (naming an industry sector that the original rule would have regulated) could be "distinctly different” with far lower costs (and, if the original objection had merit, not drastically diminished total benefits) and far less opposition than the previous though nearly-identical rule.

\footnotetext{
${ }^{210}$ In this specific case, though, we might argue that OSHA could instead better explain how Congress
} 
Interpretation 2 (even an identical rule can be reissued under "substantially different" external conditions), while it may seem to make a mockery of section 801(b)(2), also has merit. Congress clearly did not want agencies to circumvent the CRA by waiting for the vote count to change (or the White House to change hands and make a simple majority in Congress no longer sufficient) and reissuing an identical rule. Even that might not be so bad an outcome; after all, a parent's answer to a 16-year-old's question “Can I have the car keys?” might be different if the child waits patiently and asks again in two years. But we accept that the passage of time alone should not be an excuse for trying out an identical rule again. However, time can also change everything, and the CRA needs to be interpreted such that time can make an identical rule into something "substantially different" then what used to be. Indeed, the Nickels-Reid signing statement already acknowledged how important this is, when it cited the following as a good reason for an initial veto: "agencies sometimes develop regulatory schemes at odds with congressional expectations. Moreover, during the time lapse between passage of legislation and its implementation, the nature of the problem addressed, and its proper solution, can change.”211 In other words, a particular rule Congress might have favored at the time it created the organic statute might not be appropriate anymore when finally promulgated, because time can change both problems and solutions. We fail to see any difference between that idea and the following assertion: "during the time lapse between the veto of a rule and its subsequent reissuance, the nature of the problem addressed, and its proper solution, can change.” It may, of course, change such that the original rule seems even less sensible, but what if it changes such that the costs of the original rule have plummeted and the benefits have skyrocketed? In such a circumstance, we

misinterpreted the original provision in the rule. See infra Part VI.B.

${ }^{211} 142$ Cong. REC. S3684 (daily ed. Apr. 18, 1996) (joint statement of Sens. Nickles, Reid, and Stevens). 
believe it would undercut the entire purpose of regulatory oversight and reform to refuse to debate on the merits a reissued rule whose costs and benefits—even if not its regulatory textwere far different than they were when the previous iteration was struck down.

Interpretation 1 (anything goes so long as the agency merely asserts that external conditions have changed), on the other hand, would contravene all the plain language and explanatory material in the CRA. Even if the agency believes it now has better explanations for an identical reissued rule, the appearance of asking the same question until you get a different answer is offensive enough to bedrock good-government principles that we think the agency should find ways to change the costs and benefits after a veto, not just change its rhetoric about them. ${ }^{212}$

We therefore believe Interpretation 3 is the most reasonable general case, but that Interpretations 2 or 4 may be more appropriate in various particular situations. But there is one additional burden we think agencies should be asked to carry, even though it is nowhere mentioned in the CRA. The process by which a rule is developed can undermine its content, and beneficial changes in that content may not fix a suspect process, even though Congress modified with "substantially the same" the word "form," not the word "process." Indeed, much of the floor debate about ergonomics decried various purported procedural lapses: the OSHA leadership allegedly paid expert witnesses for their testimony and edited their submissions, and made closed-minded conclusory statements about the science and economics while the rulemaking record was still open, among other flaws. We think agencies should be expected to

\footnotetext{
${ }^{212}$ We conclude this notwithstanding the irony that in one sense, the congressional majority did just that in the ergonomics case-it delayed the rule for several years to require the National Academy of Sciences to study the
} 
fix procedural flaws specifically identified as such by Congress during a veto debate, even if this is not needed to effectuate a "substantially different form." 213

\section{PRACTICAL IMPLICATIONS FOR OSHA OF A COST-BENEFIT INTERPRETATION OF THE CRA}

We have argued above that the agency's fundamental obligation under the CRA is to craft a reissued rule with substantially greater benefits and/or substantially lower costs than the version that Congress vetoed. As a practical matter, we contend it should focus on aspects of the regulation that Congress identified as driving the overall unfavorable cost-benefit balance.

When, as is often the case, the regulation hinges on a single quantitative judgment about stringency (How low should the ambient ozone concentration be? How many miles per gallon must each automobile manufacturer's fleet achieve? What trace amount of fat per serving can a product contain and still be labeled "fat-free"?), a new rule can be made "substantially different" with a single change in the regulatory text to change the stringency (along with, of course, substantial changes in the Regulatory Impact Analysis tracking the new estimates of costs and benefits). The 2000 OSHA ergonomics rule does not fit this pattern, however. Although we think it might be plausible for OSHA to argue that the underlying science, the methods of control, and the political landscape have changed enough after a decade of federal inactivity on ergonomic issues that the 2000 rule could be re-proposed verbatim as a solution to a "substantially different" problem, we recognize the political impracticality of such a strategy. But thence to change the costs and benefits of the 2000 rule will require major thematic and 
textual revisions, because the original rule had flaws much more to do with regulatory design and philosophy than with stringency per se. In this Part, therefore, we offer some broad suggestions for how OSHA could make substantially more favorable the costs and benefits of a new ergonomics regulation.

\section{A. Preconditions for a Sensible Discussion About the Stringency of an Ergonomics Rule}

In our opinion, reasonable observers have little room to question the fact of an enormous market failure in which occupational ergonomic stressors cause musculoskeletal disorders (MSDs) in hundreds of thousands of U.S. workers annually ${ }^{214}$. Hundreds of peer-reviewed epidemiologic studies have concluded that exposure to risk factors such as lifting heavy objects, undertaking relentless fine-motor actions, and handling tools that vibrate forcefully can cause debilitating MSDs that affect the hands, wrists, neck, arms, legs, back, and other body parts. Most of these studies have also documented dose-response relationships: the more intense, frequent, or forceful the occupational stress, the greater the population incidence and/or the more severe the individual morbidity. In this respect, ergonomic risk factors resemble the chemical, radiological, and biological exposures OSHA has regulated for decades under the OSH Act and the 1980 Supreme Court decision in the Benzene Case - if prevailing (unregulated) exposures are sufficient to cause a "significant risk" of serious impairment of health, OSHA can impose

${ }^{213}$ See infra Part VI.B.

${ }^{214}$ According to the Bureau of Labor Statistics, there were more than 560,000 injuries, resulting in one or more lost workdays, from the category of "sprains, strains, and tears"; by 2009, that number had declined to roughly 380,000. See Bureau of Labor Statistics, Nonfatal CASES InVOlVing Days AWAY From Work: SeleCted CHARACTERISTICS, http://data.bls.gov/pdq/SurveyOutputServlet?data_tool=latest_numbers\&series_id= CHU00X021XXX6N100. 
"highly protective" ${ }^{215}$ controls to reduce the risk substantially, as long as the controls are technologically feasible and not so expensive that they threaten the "fundamental competitive structure $^{216}$ of an entire industry. ${ }^{217}$

The fundamental problem with OSHA's ergonomics regulation was that it did not target ergonomic risk factors specifically or directly, but instead would have required an arguably vague, indirect, and potentially never-ending series of ill-defined improvements in broader industrial management systems at the firm level, ones that in turn could and should have reduced stressors and thereby reduced MSDs. The decision to craft a management-based regulation ${ }^{218}$ rather than one that directly specified improvements in technological controls (a design standard) or reductions in specific exposures (a performance standard) was an understandable reaction on OSHA Assistant Secretary Charles Jeffress’ part to past history and contemporary political pressures.

In 1995, OSHA had drafted a complete regulatory text and preamble to a proposed ergonomics regulation that would have specified performance targets for the common risk

${ }^{215}$ Indus. Union Dep’t v. Am. Petroleum Inst. (Benzene Case), 448 U.S. 607 (1980).

${ }^{216}$ See Am. Textile Mfrs. Inst. v. Donovan (Cotton Dust Case), 452 U.S. 490 (1981).

${ }^{217}$ Ergonomic stressors may appear to be very different from chemical exposures, in that person-to-person variation in fitness obviously affects the MSD risk: some people cannot lift a seventy-five-pound package even once, whereas others can do so every minute without injury. However, substantial (though often unacknowledged) interindividual variability is known to exist in susceptibility to chemical hazards as well. For both kinds of hazards, each person has his or her own dose-response curve, and regulatory agencies can reduce population morbidity and mortality by reducing exposures (and hence risks) for relatively "resistant" and/or relatively "sensitive" individuals - with or without special regulatory tools to benefit these subgroups differentially.

${ }^{218}$ See, e.g., Cary Coglianese \& David Lazer. Management-Based Regulation: Prescribing Public Management to Achieve Public Goals, 37 LAW \& Soc'y REV. 691, 726 (2003) (concluding that “[t]he challenge for governmental enforcement of management-based regulation may be made more difficult because the same conditions that make it difficult for government to impose technological and performance standards may also tend to make it more difficult for government to determine what constitutes 'good management'.”). 
factors, in many industrial sectors. Of necessity, these targets in some cases involved slightly more complicated benchmarks than the one-dimensional metrics industry was used to seeing from OSHA (e.g., ppm of some contaminant in workplace air)—for example, a "lifting limit" might have prohibited employers from requiring a worker to lift more than $X$ objects per hour, each weighing $Y$ pounds, if the lifting maneuver required rotating the trunk of the body through an angle of more than $Z$ degrees. OSHA circulated this proposed rule widely, and it generated such intense opposition from the regulated community, and such skepticism during informal review by the Office of Information and Regulatory Affairs, that the agency withdrew it and went back to the drawing board. Because the most vehement opposition arose in response to the easily-caricatured extent of "micro-management" in the 1995 text (to paraphrase a familiar refrain, "the deskbound bureaucrats in Washington are trying to tell us how to build an airplane”), when OSHA began to rework the ergonomics rule in 1998, it acted as if the most important complexion of the new rule was its reversal of each feature of the old one. Where the 1995 text was proactive and targeted exposures, the 2000 text $^{219}$ was reactive, and imposed on an employer no obligation to control exposures until at least one employee in a particular job category had already developed a work-related MSD. Where the 1995 text provided performance goals so an employer could know (but also object to) how much exposure reduction would satisfy and OSHA inspector, the revised text emphasized that inspectors would be looking for evidence of "management leadership" in creating an ergonomically-appropriate workplace and "employee participation" in decisions about ergonomic design.

${ }^{219}$ See 64 Fed. Reg. 67,568 (proposed Nov. 23, 1999). 
OSHA intended this pendulum swing with respect to the earlier version in large part to provide the opposition with what (it said) it wanted-a "user-friendly" rule that allowed each employer to reduce MSDs according to the unique circumstances of his operation and workforce. Instead, these attributes doomed the revised ergonomics role, but they provide a partial blueprint for how OSHA could sensibly craft a "substantially different” regulation in the future. American business interpreted OSHA’s attempt to eschew “one size fits all” requirements not as a concession to the opposition around the 1995 text, but as a declaration of war. The "flexibility" to respond idiosyncratically to the unique ergonomic problems in each workplace was almost universally interpreted by industry trade associations as the worst kind of vagueness. Having beaten back a rule that seemed to tell employers exactly what to do, industry now argued that a rule with too much flexibility was a rule without any clear indication of where the compliance burden would end. Small business in particular characterized the lack of specific marching orders as being "left to their own devices," in the sense of federal abdication of responsibility to state plainly what would suffice. But in light of what had already transpired in 1995, and exacerbated by the publication of the final rule after the votes were cast in the Bush v. Gore election (but before the outcome was known), it turned out that OSHA opened itself up to much worse than charges of insufficient detail—it became dogged by charges that the regulatory text was a Trojan Horse, hiding an apparatus that was specific and onerous, but one it was keeping secret. The requirement (not found in the OSH Act or in its interpretations in the Benzene Case or Cotton Dust Case, but having evolved out of OSHA's deference to the instructions issued by OIRA) that OSHA compare the costs and benefits of compliance with each final rule played into this conspiratorial interpretation: because OSHA provided cost information, it was reasonable for a business to infer that OSHA knew what kinds of controls it would be requiring, and that 
inspectors would be evaluating these controls rather than the "management leadership and employee participation” to gauge the presence of violations and the severity of citations. Both the extreme flexibility of the rule and with the cost-benefit information may have been a road paved with good intentions, but ironically or otherwise these factors combined to fuel the opposition and to provide a compelling narrative of a disingenuous agency that receptive ears in Congress were happy to amplify.

Not only was OSHA's attempt to write a regulation whose crux was “choose your controls” misinterpreted as “choose our controls by reading our minds,” but it undermined any tendency of Congress to defer to the agency's conclusion that the rule had a favorable benefitcost balance. Because the projected extent of compliance expenditures depended crucially on how many firms who would have to create or improve their ergonomics management systems, and what those improvements would end up looking like, rather than on the more traditional cost accounting scenario (the price of specified controls multiplied by the number of controls necessary for regulated firms to come into compliance), opponents of the rule did not need to contest OSHA's data or price estimates - they simply needed to assert that the extreme ambiguity of the regulatory target made for much greater expenditures than OSHA's rosy scenarios predicted. The ominous pronouncements of ergonomic costs ${ }^{220}$ were the single most important factor in justifying the congressional veto, on the grounds that the costs of the regulation swamped benefits it would deliver — and the vagueness of the rule played into the hands of those who could benefit from fancifully large cost estimates. The reactive nature of the rule (most of the new controls would not have to be implemented until one or more MSD injuries

\footnotetext{
${ }^{220}$ For cost estimates ranging up to $\$ 125$ billion annually, see supra note 89 .
} 
occurred in a given job category in a particular workplace) also made OSHA's benefits estimates precarious. All estimates of reduced health effects as a function of reduced exposures involve uncertainty in dose-response, but to make future benefits contingent on future cases of harm (not merely on exposures) adds another level of uncertainty to the exercise.

Whatever the reasons for a veto under the CRA, we argued above that the affected agency’s first responsibility, if it wants to avoid being thwarted by the "substantially similar" trap, is to craft a revised rule with a much more favorable balance of benefits to costs. But because the 2000 ergonomics rule had chosen no particular stringency per se (at least not one whose level the agency and its critics could even begin to agree existed), OSHA cannot tweak the benefit-cost balance with any straightforward concessions. In the case of ergonomics, we contend that OSHA probably needs to abandon the strategy of a flexible, management-based standard, since that approach probably guarantees pushback on the grounds that the true costs of complying with a vague set of mandates dwarf any credible estimates of benefits (in addition to pushing the hot button of the "hidden enforcement manual"). In the next Section, we list some practical steps OSHA could take (motivated by a catalog of the strongest criticisms made during the floor debate on the 2000 rule, as well as our own observations about costs, benefits, and regulatory design) to comport with the CRA.

\section{B. Specific Suggestions for Worthwhile Revisions to the Ergonomics Rule}

A “substantially different” ergonomics rule would have benefits that exceeded costs, to a high degree of confidence. We believe OSHA could navigate between the rock of excessive flexibility (leading to easy condemnation that costs would swamp benefits) and the hard place of 
excessive specificity (leading essentially to condemnation that the unmeasured cost of losing control of one's own industrial process would dwarf any societal benefits therefrom), simply by combining the best features of each approach. The basic pitfall of the technology-based approach to setting standards (other than, of course, the complaint from the left-wing that it "freezes" improvements based on what can be achieved technologically, rather than what needs to be achieved from a moral vantage point) is that it precludes clever businesses from achieving (or surpassing) the desired level of performance using cheaper methods. But a hybrid rule—one that provides enough specificity about how to comply that small businesses cannot claim they are adrift without guidance, but one that also allows unlimited innovation so long as it is at least as effective as the permitted controls would be—could perhaps inoculate the issuing agency against claims of too little or too much intrusiveness. From a cost-benefit perspective, such a design would also yield the very useful output of a lower bound on a net benefit estimate, because by definition any of the more efficient controls some firms would freely opt to undertake would either lower total costs and/or reap additional benefits. It would also yield a much less controversial—and less easily caricatured—net benefit estimate, because the lower-bound estimate would be based not on OSHA's hypotheses of how much "management leadership” and “employee participation” would cost and how many MSDs these programs would avert, but on the documented costs of controls and the documented effectiveness of specific workplace interventions on MSD rates. In other words, we urge OSHA to take a fresh look at the 1995 ergonomics proposal, but to recast all the specific design and exposure-reduction requirements therein as guidance - the specifications would become "safe harbors" that employers could implement and know they are in compliance, but that they could choose to safely ignore in favor of better site-specific (“one size fits one”) solutions to reduce intolerable ergonomic stressors. 
The other major philosophical step towards a "substantially different” rule we urge OSHA to consider involves replacing ergonomic “exposure floors” with "exposure ceilings.” With the intention of reassuring many employers that they would have no compliance burden if their employees were subjected only to minimal to moderate ergonomic stressors, OSHA created a "Basic Screening Tool” demarcating exposures above which employees might have to implement controls. $^{221}$ For example, even if one or more employees developed a work-related MSD, the employer would have no obligation even to assess the job(s) or task(s) for possible exposure controls, unless the affected employee(s) were routinely exposed to stressors at or above the screening levels. These levels are low, as befits a screening tool used to exclude trivial hazards; for example, only a task that involved lifting 25 pounds or more with arms fully extended, more than 25 times per workday, would exceed the screening level and possibly trigger the obligation to further assess the situation. Unfortunately, it was easy for trade associations and their allies in Congress to misrepresent these floors as ceilings, as if OSHA had set out to eliminate all " 25 times 25 pounds workdays” rather than to treat any lifting injuries caused by occupational requirements below this level as the employee’s tough luck. ${ }^{222}$ Hence the debate degenerated into warnings about "the end of Thanksgiving” under an OSHA rule that “prohibited” grocery checkout workers from lifting 26-pound turkeys off the conveyor belt. ${ }^{223}$ In

${ }^{221}$ See Ergonomics Program; Final Rule, 65 Fed. Reg. 68,848-49 (proposed Nov, 14, 2000).

${ }^{222}$ For example, Republican Senator Don Nickles of Oklahoma began the Senate debate on the rule by flatly stating that “[F]ederal bureaucrats are saying you can do this; you can't do that. You can only move 25 lbs. 25 times a day . . . Employees would say: I have to stop; it is 8:25 [a.m.], but I have already moved 25 things. Time out. Hire more people.” 147 CONG. REC. S1833 (daily ed. Mar. 6, 2001) (statement of Sen. Nickles).

${ }^{223}$ Republican Representative Ric Keller of Florida said, "It is also true that if a bagger in a grocery store lifts a turkey up and we are in the Thanksgiving season, that is 16 pounds, he is now violating Federal law in the minds of some OSHA bureaucrats because they think you should not be able to lift anything over 15 pounds. We need a little common sense here.” 147 CONG. REC. H688 (daily ed. Mar. 7, 2001) (statement of Rep. Keller). 
a revised rule, approaching the dose-response continuum from above rather than from below would make much more practical and political sense. As with all of its health standards for chemicals, OSHA's goal (as reinforced by the "significant risk” language of the Benzene Case decision) is to eliminate where feasible exposures that are intolerably high; defining instead exposures that are not insignificantly low may help narrow this window, but it obviously backfired in the case of ergonomics. Making the tough science-policy decisions about which levels of ergonomic stressors must be ameliorated wherever feasible, just as OSHA and other agencies do routinely for substances with observed or modeled dose-response relationships, would have four huge advantages: (1) it would clearly transform the ergonomics rule into something "substantially different" than the 2000 version; (2) it would ally OSHA with the science of MSD dose-response- -because the 2000 version triggered controls upon the appearance of MSD, rather than treating certain exposures as intolerably risky regardless of whether they had already been associated with harm, it certainly made it at least appear that OSHA regarded MSDs as mysterious events, rather than the logical result of specific conditions $^{224}$; (3) it could insulate OSHA from some of the political wrangling that caused it to exempt some obviously risky major industries (e.g., construction) from the rule entirely, while subjecting less risky industry to the specter of costly controls—controlling intolerable exposures wherever they are found is a neutral means of delimiting the scope of the rule; and (4) it would shift the rhetorical burden from government to argue that small exertions might be worthy of attention, to industry having to argue that herculean exertions must be permitted. Adjusting the 
ceiling to focus mandatory controls on the most intolerable conditions is, of course, the quintessential regulatory act and the most direct force that keeps costs down and pushes benefits up—and this is the act that OSHA's management-based ergonomics rule abdicated.

Continuing with recommendations that improve the cost-benefit balance and also respond to specific "hot buttons" from the congressional veto debate, we believe that OSHA should also consider targeting an ergonomics rule more squarely at MSDs that are truly caused or exacerbated by occupational risk factors. The 2000 rule defined a "work-related" MSD as one that workplace exposure "caused or contributed to."225 But the latter part of this definition, intentionally or otherwise, subsumes MSDs that primarily arise from off-the-job activity (the easily-mocked "tennis elbow" hypothetical). On the other hand, a redefinition that simply required a medical opinion that the MSD would not have occurred absent the occupational exposure(s) would cover exposures that pushed a worker "over the edge" to a full-blown injury, but not those that add marginally to off-work exposures that are already sufficient by themselves to cause the MSD. In this regard, however, it will be important for OSHA to correct an egregious misinterpretation of the science of ergonomics bandied about freely during the congressional veto debate. Various members made much of the fact that one of the NAS panel reports concluded that “none of the common MSDs is uniquely caused by work exposures."226 Senator Kit Bond and others took a true statement about the totality of all cases of one single kind of MSD (e.g., carpal tunnel syndrome, Raynaud's phenomenon), and made it sound as if it

${ }^{224}$ The decision to make the ergonomics rule reactive rather than proactive arguably played right into the hands of opponents, who essentially argued that OSHA had come to agree with them that science did not support any dose-response conclusions about MSD origins.

${ }^{225}$ Ergonomics Program; Final Rule, 65 Fed. Reg. 68,854 (proposed Nov, 14, 2000).

${ }^{226} 147$ CONG. REC. S1853 (daily ed. Mar. 6, 2001) (statement of Sen. Bond). 
referred to every individual MSD case, which is of course ridiculous. "Crashing your car into a telephone pole is not uniquely caused by drunk driving,” to be sure—of the thousands of such cases each year, some are surely unrelated to alcohol-but this in no way means that we cannot be quite sure what was to blame in a particular case in which the victim was found with a blood alcohol concentration of, say, 0.25 percent by volume (enough to cause stupor). Many individual MSDs are caused solely by occupational exposure, and any regulation worth anything must effect reductions in those exposures that make a resulting MSD inevitable or nearly so.

The other "hot button" issue specifically mentioned repeatedly in the veto debate was OSHA’s supposed attempt to create a separate workers’ compensation system for injured employees. Paragraph ( $r$ ) of the final ergonomics rule ${ }^{227}$ would have required employers who had to remove an employee from her job due to a work-related MSD to pay her at least 90 percent of her salary for a maximum of 90 days, or until a health care professional determined that her injury will prevent her for ever resuming that job (whichever came first). OSHA deemed such a “work restriction protection” program necessary so that employees would not be deterred from admitting they were injured and risk losing their jobs immediately. But various members of Congress decried this provision of the rule as “completely overrid[ing] the State’s rights to make an independent determination about what constitutes a work-related injury and what level of compensation injured workers should receive.” ${ }^{228}$ Worse yet, because section 4(b)(4) of the OSH Act states that "[n]othing in this Act shall be construed to supersede or in any manner affect any workmen's compensation law ..., , various members accused OSHA of “exceeding [its] constitutional authority” by legislating (a new workers’ compensation system)

\footnotetext{
${ }^{227}$ Ergonomics Program; Final Rule, 65 Fed Reg 68,851 (proposed Nov. 14, 2000).
} 
rather than regulating. ${ }^{229}$ Other members disputed these allegations, noting that providing temporary (and partial) restoration of salary that would otherwise be lost during a period of incapacity is very different from compensating someone for having contributed to an injury. As Senator Edward Kennedy said, “it has virtually nothing to do with workers’ compensation, other than what has been done traditionally in other kinds of OSHA rules and regulations such as for cadmium and lead."230 Indeed, the D.C. Circuit settled this issue years ago in upholding the much more generous eighteen-month protection program in the OSHA lead standard. In United Steelworkers of America v. Marshall, ${ }^{231}$ that court held that section 4(b)(4) of the OSH Act does bar workers from asserting a private cause of action against employers using an OSHA standard, and bars workers from obtaining state compensation for a non-compensable injury just because OSHA may protect a worker against such an injury. ${ }^{232}$ But more generally, the Circuit court concluded that "the statute and the legislative history both demonstrate unmistakably that OSHA's statutory mandate is, as a general matter, broad enough to include such a regulation as MRP.”233

It is ironic, therefore, that the only mention of workers' compensation in the ergonomics rule is a provision that that allows the employer to reduce the work restriction reimbursement dollar for dollar by any amount that the employee receives under her state’s compensation

\footnotetext{
228147 CONG. REC. S1840 (daily ed. Mar. 6, 2001) (statement of Sen. Enzi)

229147 Cong. REC. S1833 (daily ed. Mar. 6, 2001) (statement of Sen. Nickles); see also supra Part II.A.

230147 ConG. REC. S1834 (daily ed. Mar. 6, 2001) (statement of Sen. Kennedy).

${ }^{231} 647$ F.2d 1189 (D.C. Cir. 1980).

232 See id.

${ }^{233} I d$. MRP is “medical removal protection,” the provision of salary while an employee with a high blood lead level is removed from ongoing exposure to lead until his blood level declines. The court's decision stated in
} 
program! $!^{234}$ If OSHA had not explicitly sought to prohibit “double dipping,” the ergonomics rule would never have even trespassed semantically on the workers' compensation system. It is tempting, then, to suggest that OSHA could make the work restriction program "substantially different” by removing the reference to workers' compensation and making it a more expensive program for employers to implement. However, the spirit of both responding to specific congressional objections and of improving the cost-benefit balance would argue against such a tactic, as would the practical danger of arousing congressional ire by using its objections against the interests of its favored constituents. It is possible that an exposure-based ergonomics rule that does not rely on the discovery of an MSD to trigger possible controls would reduce the disincentive for workers to self-report injuries, but the problem remains that without some form of insurance against job loss, workers will find it tempting to hide injuries until they become debilitating and possibly irreversible. Perhaps the administration could approach Congress before OSHA issued a new ergonomics proposal, and suggest it consider creating a trust fund for temporary benefits for the victims of MSD injuries (as has been done for black lung disease and vaccine-related injuries). Employers might find work-restriction payments from a general fund less offensive than they apparently found the notion of using company funds alone to help their own injured workers.

OSHA could obviously consider a wide variety of other revisions to make a new ergonomics rule "substantially different" and more likely to survive a second round of congressional review. Some of the other changes that would accede to specific congressional

relevant part: "We conclude that though MRP may indeed have a great practical effect on workmen's compensation claims, it leaves the state schemes wholly intact as a legal matter, and so does not violate Section 4(b)(4)." Id.

${ }^{234}$ This subsection also allows the employer to reduce the benefits for each dollar of income the worker earns from other employment made possible by the temporary inability to perform her normal duties. Id. 
concerns from 2001—such as making sure that businesses could obtain all the necessary guidance materials to implement an ergonomics program free of charge, rather than having to purchase them from private vendors at a cost of several hundred dollars ${ }^{235}$ —are presumably "no-brainers" (this one being even easier to accommodate now that it would have been before the boom in online access to published reports). Other redesigns are up to OSHA to choose among based on its appraisal of the scientific and economic information, with (we would recommend) an eye toward changes that would most substantially increase total benefits and/or reduce total costs.

One other category of change we recommend even though it is more work for the agency than any literal reading of "substantially the same form" would require. The CRA is concerned with rules that reappear in the same "form," but it is also true that the process leading up to the words on the page matters to proponents and opponents of every regulation. The ergonomics rule faced withering criticism for several purported deficiencies in how it was produced. We think the CRA imposes no legal obligation upon OSHA to develop a "substantially different" process the second time around—after all, "form" is essentially perpendicular to "process," and had Congress wanted to force an agency to change how it arrived at an offensive form, it surely could have said "reissued in substantially the same form or via substantially the same process" in section 801(b)(2). However, well-founded complaints about flawed process should, we believe, be addressed at the same time an agency is attempting to improve the rule's form in the costbenefit sense. Although courts have traditionally been very reluctant to rescind rules signed by

${ }^{235}$ See 147 Cong. REC. S1841 (daily ed. Mar. 6, 2001) (statement of Sen. Enzi). 
an agency head who has telegraphed her personal views on the subject at issue, ${ }^{236}$ we assume the Obama administration or that of a future executive would be more careful to avoid the appearance a general bias for regulation as a "thrill” (or against it as a "menace”) by the career official leading the regulatory effort. ${ }^{237}$ But we do not expect OSHA to overreact to ten-year-old complaints about the zeal with which it may have sought to regulate here. Other complaints about the rulemaking process in ergonomics may motivate a "substantially different” process, if OSHA seeks to repromulgate. For example, Senator Tim Hutchinson accused OSHA of orchestrating a process with "witnesses who were paid, instructed, coached, practiced, to arrive at a preordained outcome, ${ }^{238}$ and although an agency need not confine itself to outside experts who will testify pro bono, we suggest it would be politically unwise for OSHA to again edit the testimony of the experts it enlists. Similarly, a different ergonomics rule that still had the cloud of improper and undisclosed conflict-of-interest in the choice of outside contractors to do the bulk of the regulatory impact analysis work ${ }^{239}$ would, we believe, fail to comport with the spirit of section 801(b)(2), in that it would have "circumvented" the instructions of at least some in Congress to "clean up” the process.

${ }^{236}$ See, e.g., United Steelworkers of Am. v Marshall, 647 F.2d 1189 (D.C. Cir. 1980) (finding that the head of OSHA "served her agency poorly by making statements so susceptible to an inference of bias," but also finding that she was not "so biased as to be incapable of finding facts and setting policy on the basis of the objective record before her").

${ }^{237}$ See supra note 88.

238147 ConG. ReC. S1857 (daily ed. Mar. 6, 2001) (statement of Sen. Hutchinson).

${ }^{239}$ See Letter from David McIntosh, U.S. House of Representatives, to Alexis M. Herman, Sec’y of Labor, U.S. Dep’t of Labor (Oct. 30, 2000), available at http://insidehealthpolicy.com/Inside-OSHA/Inside-OSHA11/13/2000/mcintosh-letter-to-herman/menu-id-219.html. McIntosh alleged that the career OSHA official who led the ergonomics rulemaking did (with OSHA's approval) assign task orders to a consulting firm that she had been an owner of before coming to government (and after signing a Conflict of Interest Disqualification requiring her to recuse herself from any such contractual decisions involving her former firm). 
On the other hand, we think some objections to the process by which a rule is developed ought more properly to be the subject of judicial review rather than congressional interference. members of Congress accused OSHA of not having enough time to read, let alone digest and thoughtfully respond to, the more than 7000 public contents received as late as August 10, 2000, before the final rule was issued barely three months later. ${ }^{240}$ Sen. Enzi also said that OSHA "took the comments they got, and they opposed everything and incorporated things in this that were worse than in the law [sic] that was passed." ${ }^{241}$ But although a reviewing court could not punish OSHA for crafting a rule with costs exceeding benefits, or for engaging in conduct with expert witnesses that Congress might find unseemly, the courts are empowered and required to judge whether OSHA arbitrarily ignored evidence in the record, or twisted its meaning. The CRA, therefore, should emphasize those substantive—and process—concerns for which aggrieved parties have no other remedy.

\section{RECOMMENDATIONS TO AMEND THE CRA}

Only one attempt has been made to amend the CRA in the fourteen years since its passage, an inconsequential bill (H.R. 2247) that unanimously passed the house in June 2009, and that would have eliminated the requirement that an agency transmit each final rule to each house of Congress (leaving the Comptroller General as the only recipient). Here we suggest several more substantive changes Congress should consider to improve the CRA, emphasizing the reissued-rules problem but including broader suggestions as well.

\footnotetext{
${ }^{240}$ See, e.g., 147 CONG. REC. S1839 (daily ed. Mar. 6, 2001) (statement of Sen. Enzi).

${ }^{241}$ Id. at $\mathrm{S} 1837$.
} 
Congress should explicitly clarify the meaning of "substantially the same" along the lines we suggest (that any rule with a substantially more favorable balance between benefits and costs should be considered "substantially different" and not vulnerable to a preemptory veto). In the rare cases where a prior congressional mandate to produce a narrowly-tailored rule collides headon with the veto of the rule as promulgated, Congress has already admitted that it owes it to the agency to "make the congressional intent clear regarding the agency's options or lack thereof after enactment of a joint resolution of disapproval.,242 But there is currently no legal obligation for Congress to do so. In a hypothetical case where Congress has effectively said "promulgate this particular rule” and then vetoed a good-faith attempt to do just that, it seems particularly inappropriate for Congress not to bind itself to resolve the paradox.

Congress could also go much further and take on more responsibility, by living up to the literal promise embodied in the signing statement. The predicate to the clause quoted above reads: "[T]he authors intend the debate on any resolution of disapproval to focus on the law that authorized the rule.”243 That is to say, whenever Congress disapproves of a rule, it should surround what Cohen and Strauss called the "the Delphic 'No!',244 with some attempt to explain the "why 'No'?” question the agency will rightly be preoccupied with as it regroups or retreats. From the agency's point of view, it is bad enough that Congress can “undo in 10 hours what it took OSHA 10 years to craft," but to do so without a single word of explanation, beyond the ping-pong balls of opposing rhetoric during a floor debate, smacks more of Congress flexing its muscle than truly teaching the agency a lesson. Indeed, it is quite possible that the act of

\footnotetext{
242142 Cong. REC. S3686 (daily ed. Apr. 18, 1996) (joint statement of Sens. Nickles, Reid, and Stevens).

${ }^{243}$ Id. (emphasis added).
} 
articulating an explanatory statement to be voted on might reveal that there might be fifty or more unhappy Senators, but no majority for any particular view of whether and why the rule should be scrapped.

We hasten to add, however, that this bow to transparency and logic should be a two-way street; we enthusiastically endorse the proposal Professor Strauss made in 1997 that the CRA should be "amended to provide that an agency adopting the same or 'substantially the same' rule to one that has been disapproved must fully explain in its statement of basis and purpose how any issues ventilated during the initial disapproval process have been met." ${ }^{245}$ We would go further, however, and suggest that the overwhelmingly logical time to have the discussion about whether a reissued rule runs afoul of the "substantially the same" provision is when the new rule is proposed, not after it is later issued as a final rule. Surely needless costs will be incurred by the agency and the interested public, and other benefits will be needlessly foregone in the bargain, if Congress silently watches a regulatory proposal go through notice and comment that it believes may be invalid on "substantially the same" grounds, only to veto it at the finish line. We suggest that whenever an agency is attempting to reissue a vetoed rule on the grounds that it is not "substantially the same," it should be obligated to transmit the Notice of Proposed Rulemaking (NPRM) to both houses, and then that Congress should have a window of time (we suggest sixty legislative days) to decide whether the proposal should not be allowed to go forward on "substantially the same" grounds (with silence denoting assent). Under this process,

${ }^{244}$ Daniel Cohen \& Peter Strauss, Regulatory Reform and the $104^{\text {th }}$ Congress: Congressional Review of Agency Regulations, 49 Admin. L. Rev. 95, 105.

${ }^{245}$ Hearing Before the Subcomm. on Comm. \& Admin. Law of the H. Comm. on the Judiciary, 104th Cong. (Mar. 6, 1997) (statement of Peter L. Strauss). Assuming that our proposal immediately above was adopted, we would interpret Strauss' amendment as then applying only to "issues specifically called out in the list of particulars 
failure to halt the NPRM would preclude Congress from raising a "substantially the same" objection at the time of final promulgation, but it would of course not preclude a second veto on any substantive grounds - the agency would still be vulnerable to charges that it had found a second way to issue a rule that did more harm than good. With this major improvement in place, a vague prohibition against reissuing a similar rule would at worst cause an agency to waste half its rulemaking resources.

The CRA veto process might also be improved by permitting a resolution of disapproval to strike merely the offending portion(s) of a proposed rule, leaving the rest intact. If, as a clearly hypothetical example, the only thing that Congress disliked about the ergonomics resolution was the additional entitlement to benefits different from those provided by state workers' compensation laws, it could have simply struck that provision. Charles Tiefer has made the interesting observation that one would not want to close military bases this way (but rather a take-it-or-leave-it for the proposed list as a whole), to avoid horse-trading ${ }^{246}$ —but a set of regulatory provisions can be different: it is not zero-sum in the same way. The allowance for severability would pinpoint the offending portion(s) of a proposed regulation and therefore give the agency more clear guidance as to what sort of provisions are and are not approved.

Severability would have the added benefit of lowering the chances of there being a null set of reasons for veto (i.e., the current generic joint resolution format may be passed and overturn a regulation even though a single substantive "reason” does not have majority support in Congress). Suppose, for example, that the Federal Aviation Administration (FAA) proposed

contained in the expanded text of the actual resolution of disapproval”- not to any issue raised by any individual member of Congress during the floor debate.

${ }^{246}$ Tiefer, supra note 120 , at 479. 
an updated comprehensive passenger safety regulation that included two unrelated provisions.

First, due to passengers' disobedience of the limitations on in-flight use of personal electronic devices and mobile phones, the rule banned possession of personal electronics as carry-on items. Second, in order to ensure the dexterity and mobility of those assisting with an emergency evacuation, the rule increased the minimum age for exit-row seating from fifteen to eighteen. If thirty Senators disliked solely the electronics ban, but thirty different Senators disliked only the exit row seating restriction, then under the current law the entire regulation is at risk of veto even though a majority of Senators approved of both of the two provisions. An ability to strike just the offending portion of a regulation decreases the potential ${ }^{247}$ for this sort of "null set" veto.

Currently, the CRA does not afford the agency issuing a rule the opportunity that a defendant would have under the Confrontation Clause to answer charges about the conduct at issue. Even within the confines of an expedited procedure, and recognizing that the floor of Congress is a place for internecine debate as opposed to a hearing, the CRA could still be amended to allow some limited "dialogue” between the agency whose work is being undone and the members. Perhaps in conjunction with a requirement (see above) that Congress specify the reasons for a resolution of disapproval, the agency should be allowed to enter a response into the official record indicating any concerns about misinterpretation of the rule or the accompanying risk and cost analyses. This could, of course, become somewhat farcical in a case (like the ergonomics standard) where the leadership of the agency had changed hands between the time of promulgation and the time of the vote on the disapproval-presumably, Secretary Chao would

${ }^{247}$ Admittedly, severability would not entirely eliminate the possibility-the risk would still remain where dueling minorities of legislators opposed the same provision but for different reasons. For example, if EPA were to propose an ozone standard of 75 ppb, the provision is at risk of being vetoed if thirty Senators think the standard should be 25 ppb while another thirty Senators think it should be 200 ppb. 
have declined the opportunity to defend the previous administration's ergonomics standard on factual grounds. However, each agency’s “Regulatory Policy Officer” could be empowered to craft such a statement. ${ }^{248}$

\section{CONCLUSION}

The CRA can be a helpful hurdle to trim excesses and spur more favorable actions from a CBA standpoint—but it makes no sense to foreclose the agency from doing what Congress wants, under the guise of the "substantial similarity" provision. OSHA should not reissue the ergonomics rule in anything like its past form—not because of "substantial similarity," but because it was such a flawed rule in the first place. But a different rule with a more favorable cost-benefit ratio has been needed for decades, and "substantial similarity" should not be raised again lightly, especially since at least ten years will have passed and times (will) have changed.

The history and structure of the CRA, and its role in the larger system of administrative law, indicate that the substantial similarity provision should be interpreted narrowly. More specifically, it seems that if, following disapproval of a rule, the agency changes its provisions enough that it alters the cost-benefit ratio in a significant and favorable way, and at least tries in good faith to fix substantive and procedural flaws, then the new rule should not be barred under the CRA—it can still be vetoed a second time, but for substantive reasons rather than a technicality. The framers of the CRA were concerned with federal agencies creating costly

\footnotetext{
${ }^{248}$ Note that these officers usually were career appointees, who would therefore generally hold over when administrations changed. See Exec. Order No. 12,866. President Bush issued an executive order that redefined these officers as being political appointees, but President Obama rescinded that order in January 2009. See Exec. Order No. 13,422.
} 
regulatory burdens with few benefits, and this consideration arose again in the debates over the OSHA ergonomics rule. The disapproval procedure-with its expedited debates, narrow timeframe, and failure to provide for severability of rule provisions—suggests that the substantial similarity provision is not intended to have broad effects on an agency’s power to issue rules under its organic statute, especially in a system in which we generally defer to agencies in interpreting their own delegated authority. Instead, the history and structure of the procedure suggest that the CRA is intended to give agencies a second chance to "get it right." In an ideal world, Congress would monitor big regulations and weigh in at the proposal stage, but "sending them back to the drawing board” is what the CRA most fundamentally does, and therefore it is fundamentally important that such a drawing board be left available. 